University of Chicago Law School

Chicago Unbound

Journal Articles

Faculty Scholarship

1959

\title{
Public Prosecutions in England, 1854-79: An Essay in English Legislative History
}

Philip B. Kurland

D. W. M. Waters

Follow this and additional works at: https://chicagounbound.uchicago.edu/journal_articles

Part of the Law Commons

\section{Recommended Citation}

Philip B. Kurland \& D. W. M. Waters, "Public Prosecutions in England, 1854-79: An Essay in English Legislative History," 1959 Duke Law Journal 493 (1959).

This Article is brought to you for free and open access by the Faculty Scholarship at Chicago Unbound. It has been accepted for inclusion in Journal Articles by an authorized administrator of Chicago Unbound. For more information, please contact unbound@law.uchicago.edu. 


\title{
PUBLIC PROSECUTIONS IN ENGLAND, 1854-79: AN ESSAY IN ENGLISH LEGISLATIVE HISTORY
}

\author{
Philip B. KurLand* and D. W. M. Waters**
}

In this country, though probably this country only, the result of the experience of nearly eight centuries has been to establish the principles that a criminal trial differs from a civil action principally in the character of the damages ultimately awarded. In the one case a man is tried for the sake of exacting from him his life or his liberty, as in the other case he is sued for the sake of exacting from him satisfaction for the breach of an obligation, or for the infliction of an injury. ... There is no public functionary whose duty it is to investigate the charges and to obtain and arrange the evidence required to support them. The prosecutor is generally a private person, and has never, as such, any official authority. He employs his own attorney just as he would in a civil action, and he is practically the dominus litis.

Stephen, The Criminal Law and the Detection of Crime, 2 Cornhill Magazine 697, 697-98 (1860).

\section{INTRODUCTION}

THE NINETEENTH-CENTURY movement for reform of the English police system has been the subject of numerous studies in recent years. ${ }^{1}$ The equally well-born movement for public prosecutors has remained in the realm of the unknown. ${ }^{2}$ Thus, perhaps, is

* Professor of Law, The Law School, The University of Chicago.

** Lecturer in Law, University College, University of London; sometime Visiting Professor of Law, The Law School, The University of Chicago.

The authors wish to express their gratitude to Dr. Henry Allen Moe and the Guggenheim Foundation which made this and other studies of the English prosecutorial system possible. They also indebted to Mary Jane K. Kurland for the assistance she has rendered in the preparation of these studies.

${ }^{1}$ For the most extensive of these studies, see 3 Radzinowicz, A History OF ENGlish Criminal Law: The Reform of the Police (1957).

"See, e.g., Mathew, The Office and Duties of the Director of Public Prosecutions I (1950). 
success distinguished from failure. Twice in contemporary English history did the movement come close to success. First, in the third quarter of the nineteenth century, and again, in the early years of the twentieth. Both times, the concept of public prosecutions, in the forms they have taken in the United States, on the Continent, and, indeed, in Scotland and Ireland, was rejected. This article is concerned with the first of these attempts in the arena offered by Parliament. Sponsored by the greatest names in English law, demanded by the felt necessities of the times, pushed by the great organs of the press and the journals, indeed, inevitable in the light of Dicey's thesis, it was defeated by " $\mathrm{a}$ few country gentlemen", and a general feeling of fear of Continental criminal jurisprudence.

Necessary for an understanding of the legislative contest is the picture, however elementary may be its presentation here, of the prosecutorial system as it existed in England at the time that our tale begins, circa 1850 . In the background, one should note a most inadequate constabulary, largely nonprofessional, sometimes corrupt, usually uneducated, often incompetent, a long way, indeed, from the very efficient English police which we know today; ${ }^{3}$ both legal professions-the barristers as well as the solicitors-fallen from grace; $;^{4}$ the upper levels of the judiciary made up in large measure of faithful politicos; ${ }^{5}$ committing magistrates with no knowledge of the law, almost entirely dependent upon their clerks for instructions on the subject ${ }^{6}$ and not entirely free from Home Office dictation; ${ }^{7}$ and the brooding omnipresence of "law reform" more effectively advocated by the public than by those most directly concerned..$^{8}$ (The reader may draw his own comparisons with the American scene, both past and present.)

A contemporary description of a part of the foreground of the picture may be had from the Edinburgh Review: ${ }^{\circ}$

\footnotetext{
${ }^{3}$ See Radzinowicz, op. cit. supra note $t$.

4 See Woodward, The AGe of ReForm, 1815-70, at 16-17 (1938); THe ENGLish Bar, 23 LAW Magazine 126, 145 (1867); Spectator, Nov. 10, 1855, p. 1243.

'See 17 Economist 750 ( 1859 ); Laski, Studies in LaW and Poltics 168 (1932).

'The continuance of this condition is reflected in Williams, The Proof of Guilt 289-93 (1955).

'See, e.g., Cecil, Melbourne 206 (1954).

${ }^{8}$ See, e.g., Spectator, Dec. 4; 1858, p. 1274; I LaW Magazine 795, 811 (1872); WOODWARD, op. cit. supra note 4.

- Criminal Procedure in Scotland and England, roo EdINBurgh REv. 343, 353-54 $\left(185^{8}\right)$.
} 
It would be difficult to make an intelligent foreigner believe that in ordinary cases it is left very much to chance to determine, not only who the prosecutor shall be, but whether there shall be any prosecution at all. Except in cases of high treason or sedition, it is no part of the official duty of the Attorney-General to institute a prosecution, although it frequently happens that he does so when a crime of more than usual magnitude has been committed, or when the offense is one in which the public takes an unusual degree of interest. ...

But in all other cases it is left to the committing magistrate to determine who the prosecutor shall be. Sometimes it is the party injured, or, if he be dead, his friends or representatives. Sometimes it is the policeman who has been employed to get up, as it is called, the evidence. [Most often it was the magistrate's clerk. ${ }^{10}$ ] And often the prosecution is dropped altogether because nobody feels sufficient interest to go on with it. It must also be borne in mind that although the Crown is always nominally the prosecutor, and the two parties at the trial are the Queen and the prisoner, yet in reality where there is a private prosecutor, the conduct of the case is left entirely to him, and he employs his own attorney to prepare the evidence and retain counsel.

Moreover there is no settled rule applicable in all places alike; and in consequence there is no uniformity of system throughout England. . . .

Surely such a state of things as this is discreditable to English jurisprudence. It may be alleged indeed of it, as has so often been said of many of our institutions, that the practice is better than the theory. . . . It does not work well when it produces such results as have been shown to exist, and all that can be said in its favour is, that much more evil might be expected to flow from it than experience tells us is actually the case. There is a corrective in public opinion declaring itself through the medium of the public press, which prevents many abuses which would otherwise be the almost inevitable consequence of such defects.

Whoever the prosecutor, the idealized procedure for indictable offenses at that time approximated that of today. ${ }^{11}$ Certainly by the middle of the nineteenth century, the role of the magistrate had tended

\footnotetext{
${ }^{20} \mathrm{By}$ this time, the borough magistrates' clerks were not acting in this capacity. The Law Times frequently and violently condemned the practice 'of magistrates' clerks acting as attorneys against such persons as are committed by the magistrates for whom they act." 2 L.T. 259 (1843); see also $18 \mathrm{id}$. at 228, 233 (1852); 21 id. at 20r, $213(1853) ; 48$ id. at $464(1876)$. But the quoted editorial raised a storm of protest. See, e.g., 2 id. at $278,298,322,342,393$.

21 The most significant change since that time has been the progressive atrophy of the function of the grand jury, which has culminated in its abolition in the Administration of Justice (Miscellaneous Provisions) Act, 1933, 23 \& 24 Geo. 5, c. 36; Criminal Justice Act, 1948, I1 \& 12 Geo. 6, c. 58 .
} 
to shift from that of investigator, inquisitor, and prosecutor ${ }^{12}$ to that of a judge at a preliminary criminal hearing. ${ }^{13}$ Proceedings were initiated by the prosecutor or police who caused the accused to be brought before the magistrate, either with or without the assistance of process issued from the court. Then, in the presence of the defendant, the prosecutor or police presented evidence in an attempt to make out a prima facie case of guilt. This evidence might consist of testimony of the prosecutor or police, or of witnesses other than the prosecutor, or of both. In any event, by this period, the accused had the right of cross-examination of the prosecution witnesses, probably through a solicitor or counsel of his own choosing if he could afford it. The justice's clerk was required to record the testimony in the form of depositions which were signed by the witnesses and the magistrate. If a prima facie case was made out by the prosecution witnesses, the defendant was given a limited opportunity to make a statement and to call witnesses of his own, ${ }^{14}$ whose testimony was similarly reduced to depositions by the clerk. The magistrate, depending largely on the recommendation of his clerk, then decided whether to release the prisoner, or to detain him for trial or release him on bail. If the decision was adverse to the accused, the prosecutor-often the clerk was named-and the witnesses were bound over for further proceedings.

The next step in the prosecution was for the prosecutor or his solicitor to instruct the clerk of assize if the trial were to be at the assizes, ${ }^{16}$ or the clerk of the peace if the trial were to be at quarter sessions, ${ }^{10}$ to

\footnotetext{
${ }^{12}$ But see 2 L.T. 323, 509 (1844); 9 id. at 256 (1847).

${ }^{13}$ Sir John Jervis's Act, I 1 \& 12 Vict., c. 42 (1848).

${ }^{14}$ See Stephen, Suggestions as to the Reform of the Criminal Law, z NiNeteEnTH CENTURY 737 (1877).

${ }^{15}$ Solicitors retained for the prosecution often failed to appear at the assizes, but merely sent their briefs, by reason of the fact that the fees involved did not compensate for the expense of an appearance. See, e.g., 21 L.T. 9 (2853).

The assizes may be characterized as the courts held by High Court judges, of their commissioners, on circuit in various parts of the country. In the London metropolitan area, the Central Criminal Court performed the functions of the assize court in criminal cases.

${ }^{16}$ Outside of the cities, the quarter sessions were, as their name indicates, quarter annual sessions of a court made up, in theory, of all of the justices of the peace of the county in which the court was held. "If all the justices had attended it would in some counties have amounted to a few hundreds; no such vast concourses did occur, but it was not unusual to find Quarter Sessions with twenty or more justices on the bench. . . . In borough Quarter Sessions the position is very different, for instead of the justices there is a Recorder, who is a barrister of at least five years' standing appointed by the Crown and paid for his services. It is not a full-time office, and thus leaves the holder free for private practice; he may also be in Parliament, though not for the borough of
} 
draw the indictment, largely on the basis of the depositions. Or the prosecutor or his solicitor might himself draw the indictment. The prosecutor and his witnesses, whose names were indorsed on the indictment, then appeared and gave testimony before the grand jury, which also had the benefit of the depositions for purposes of its deliberations. If a majority of the grand jury believed that a case had been made out against the accused, it returned the indictment indorsed "true bill"; otherwise it indorsed the indictment "no true bill," and the accused and the witnesses were discharged. A return of "no true bill" was not res adjudicata, and the prosecutor was free to come back again and again in his efforts to secure a "true bill." Indeed, a prosecutor was free to choose a different path to secure the same result: instead of going first to the magistrate for preliminary hearings, he was free to present his bill of indictment and witnesses directly to the grand jury for its decision. Under either procedure, if the grand jury returned a "true bill," the next step was the arraignment of the defendant in the appropriate court, where he was given an opportunity to plead. If the plea was "not guilty," the case went to trial.

Some Early Demands for a System of Public Prosecutions

The remedy most often suggested for the problems emphasized by the Edinburgh Reviero was a "public prosecutor," although this term meant different things to different people. ${ }^{17}$ In I798, a Select Committee had fruitlessly recommended a reform under this shibboleth. ${ }^{18}$ Jeremy Bentham had developed not one, but two complete legislative programs to cure some of the abundant evils of private prosecutions, ${ }^{19}$ the first as early as 1802 . Patrick Colquhon had framed a similar device. ${ }^{20}$ In 1816, William Fielding, son of Henry Fielding, testified before the Select Committee on the State of the Police of the Metropo-

which he is recorder." Jacrson, The Machinery of Justice in England 9o (2d ed. 1953).

${ }^{17}$ It has been suggested, we think erroneously, that the King's serjeants and the coroners fulfilled the duties of public prosecutors in the $13^{\text {th }}$ century. See 4 Sor. J. 71415 (1860).

${ }^{18}$ See Twenty-Eighth Report of Committee on Finance, etc., [1810] IV PArLIAMENTARY PAPERS 415.

${ }^{10}$ See 4 Works OF Jeremy Bentham $384-406$ (Bowring ed. 1842); 9 id. at 57077.

${ }^{20}$ See Colquhon, Treatise on the Police of the Metropolis $21,26,426-27$, $430-32,539,615,646$ ( 6 th ed. 1800). Colquhon had testified to the same effect before the Committee referred to in note 18 supra. 
lis and suggested the adoption of a public "accuser," but the idea was specifically rejected by the 1818 Committee considering the police problems. ${ }^{21}$ Both Sir Samuel Romilly ${ }^{22}$ and Sir Robert Peel, ${ }^{23}$ when he was Home Secretary in I826, saw merit in the idea, as did Lord John Russell when he was Home Secretary. ${ }^{24}$ Lord Brougham stated, in 1855 , that serious parliamentary consideration had been given the idea in I833. ${ }^{25}$ In I845, the Commissioners on Criminal Law in their Eighth Report, after cataloguing some of the deficiencies of the existing system, asserted that the "direct and obvious course for remedying such defects would consist of the appointment of public prosecutors."20 But the Commissioners were too busy "to recommend any specific course." An appendix to their report contained an incisive comment by Lord Chief Justice Denman, dated December 24, I843, which also suggested the necessity for and feasibility of a system of public prosecutors. ${ }^{28}$ And the suggestion was reiterated in 1853 before the Select Committee on the Police. ${ }^{29}$ The newspapers had taken up the cry. ${ }^{30}$ All of these

\footnotetext{
${ }^{2 x}$ Minutes of Evidence Taken Before the Committee on the State of the POLICE OF THE METROPOLIS (1816); Third Report from the Committee on the State of the Police of the Metropolis [1818] VIII PARLIAMENTARX PAPERS 32.

${ }^{22}$ See 3 Memoirs of Sir Samuel Romilly 372 n. I (1840). "For want of a public prosecutor, the administration of the criminal law is attended with great partiality, and with great uncertainty, the consequence of which is that the first principles of justice are outraged, and the great object of all penal jurisprudence, namely the frustration of crime, is in a great degree frustrated." The quotation is taken from a speech delivered by Lord Brougham before the Bradford Social Science Congress on Oct. 10, 1859, and is contained in a letter to the Solicitors Journal. See 4 SoL. J. 26 (1859). We have been unable to find any publication of Romilly's ideas on this subject, but it is clear that Brougham did have access to Romilly's papers, including the one on Public Prosecutors. See I Romilly, Memorrs xvi (1840).

${ }^{23}$ See 14 Parl. Deb. (2d ser.) 1232 (1820).

${ }^{24}$ See Eighth Report of the Commissioners on Criminal LaW 320-21 (1845); 46. L.T. 164 (1849).

${ }^{25}$ This statement was made in testimony before the Select Committee of the House of Commons on Public Prosecutors. Brougham there stated that he had previously testified at length on the subject before a parliamentary committee in 1833 , but that the ininutes of evidence were never published and the fire which destroyed the building of Parliament in 1834 also destroyed the records. Minzttes of Evidence to the Report of the Select Committee on Public Prosecutions, [1854-55] XII Paritamentary Papers I [hereinafter referred to as Minutes]. We have been unable to find any corroboration of this statement of Brougham's.

${ }^{20} \mathrm{P} .25$. ${ }^{97} \mathrm{Ibid}$ " P. $2 \mathrm{II}$.

${ }^{20}$ Minutes of Evidence TẠEen Before the Select Committee on Police 55 ( 1853$)$.

${ }^{30}$ See, e.g., the references in the Times, Dec. 19, 1850, p. 5, col. 3; Dec. 17, 1850 , p. 4, cols. 5, 6; see also Laurie, An Inquiry into the Use and Abuse of Grand Jutries, 2 L.T. $216(1843)$.
} 
items contributed to the ultimate enactment of the Prosecution of Offenses Act of $1879 .^{31}$ But the first substantial parliamentary step toward the enactment of such legislation of which we have found record was taken by the introduction of a bill by Mr. John George Phillimore $^{32}$ in the House of Commons during the I854 session.

\section{II}

THE I854 Bill

In offering his bill, Phillimore told the House of Commons that: $:^{33}$

The Bill had for its object to simplify and facilitate the course of public justice which had been hitherto in a most discreditable state. Under the present neglected state of our law, after the proceedings before the magistrate are closed, it was left open to the ability or zeal of a private prosecutor whether the greatest criminal should be brought to justice, or whether he should, as was too frequently the case, escape with impunity. There was little doubt that if the Bill became law, the country would be relieved from great and unnecessary expenses for under the present state of things, frivolous prosecutions were of frequent occurrence, by which expenses were multiplied exceedingly.

He went on to catalogue some of the existing evils: arrangements between attorneys and police to secure prosecutions; the purchasing of

${ }^{31}{ }_{42} \& 43$ Vict. c. 22 (1879). Later enactments include Prosecution of Offences Act, $47 \& 48$ Vict. c. 58 ( 1884 ); an Act to Amend the Prosecution of Offences Acts, 1879 and 1884,8 Edw. 7 c. 3 (1908).

${ }_{32}$ Phillimore was a Bencher of Lincoln's Inn and Reader in Constitutional Law and Legal History at the Inns of Court. He had come to Parliament in 1852 , the same year in which he took silk. He was also an author of legal treatises which included INTRODUCTION TO THE STUDY OF ROMAN LAW (1851); AN INAUgURAL LeCtURE ON JuRisprudence and a Lecture on Canon LaW (1851); Principles and Maxims of JuRIsprudence (1856); Influence of the Canon Law, in Oxford Essays (1860); and Private Law among the Romans (1863). At least some of these writings were of doubtful value. See 118 Edingurgh Rev. 523 (1863); I7 LAW MAgazine 64 (1864). The legal botanists of today who call themselves jurisprudes would probably classify him as a precursor of the "legal realists." See, especially, his THovgrts on LAw REFORM 2, 23-24 (x847). He was a man of courage, not reticent to take on Croker, see A LetTer to the Right Hon. J. W. Croker (1846), and Brougham, see THOUGHTS ON LAW REFORM 44 et seq. (1847), without hiding behind the cloak of anonymity so often used even by the great figures of the day. See EVERETT, THE PARTY of Humanity 8-11 (1939). Croker, it will be remembered, was the man on whom the character of Rigby was based in Disraeli's Coningsby. Conflicts with Brougham were not unexpected from a self-styled follower of Bentham. See BENTHAM, LORD Brovgham Displayed (1832).

${ }^{28} 130$ PARL. DEB. (3d Series) 666 (1854) [Hereinafter, the pertinent volumes of this series will be desiguated simply as HANSARD.] 
police testimony or silence by the defence; mismanagement of prosecutions for want of effort, talent, or money; the inability of the poor to bring prosecutions against those who had injured them; and the in. ability of defendants to pay the expenses of bringing forward witnesses to prove their innocence. "The object of the present Bill," he continued, "was to withdraw from a sphere of private animosity, compromise, and revenge that which ought never to be left to such chances and to see that justice was properly administered."34

The Phillimore bill ${ }^{35}$ provided for the appointment of two sets of public officials: public prosecutors and district agents. For each of the circuits traveled by the judges of the assizes, the Lord Chancellor was to appoint a public prosecutor, who was to be an experienced barrister, "to conduct ... therein all Criminal Prosecutions." The public prosecutor was to be paid an excellent salary and was to be a permanent official, removable only for cause after hearing by the Lord Chancellor and the Lord Chief Justice. It was to be the duty of the public prosecutor, after receiving a statement of the evidence and copies of the depositions taken before a magistrate or justice of the peace, which were to be transmitted to him by the appropriate district agent, to render a written opinion as to whether the evidence was sufficient to justify committing the defendant for trial "and whether the prosecution of such accused Persons will be conducing to the Ends of Public Justice"3r or whether the accused should be released. The opinion was not to bind the magistrate, but rather to guide further action of the district agent. $^{38}$ In addition, the public prosecutor was to advise district agents, when so requested, whether a prosecution should be instituted, what evidence was to be adduced at the trial or on examination, "and on any other Fact, Circumstance or Emergency arising before the Trial of any indictable offenses whatsoever." ${ }^{39}$ Finally, the public prosecutor was to conduct the trials at the assizes and the Central Criminal Court. Provision was also made for the appointment of temporary deputy public prosecutors and permanent assistant public prosecutors, the latter

${ }^{34} I d$. at 666-67.

${ }^{38}$ [1854] V Parliamentary Papers 571.

${ }^{30}$ Id. \& II.

${ }^{37} \mathrm{Id}$. $\mathrm{IV}$.

${ }^{38}$ The opinion would also have an effect on the payment of costs to the prosecutor. In the event a private prosecutor undertook the action contrary to the opinion of the public prosecutor, he would not be entitled to costs, except on special order of the court that the prosecution had been properly inaintained.

30 [1854] V ParLiaMientary Papers 57I, § IV. 
primarily for the purpose of conducting criminal trials at the quarter sessions. ${ }^{40}$

The Lord Chancellor was also to appoint for each district, the boundaries of which he was empowered to define, one or more district agents. These district agents were to be experienced solicitors and were to be appointed "for the Purpose of discovering, bringing to light, collecting and preparing the Evidence and performing the Duties of an attorney for the Prosecution in all Cases arising within his District."11 $\mathrm{He}$, too, was to be salaried, but he was subject to removal at the pleasure of the Crown. His duties as described in the bill were:42

to apply for Warrants, to attend at and conduct the Examination of Witnesses at Police Courts and before Justices of the Peace when occasion shall require, to investigate the Evidence relating to any Crime committed within his District, to transmit copies of all Depositions of Witnesses and Statements of Prisoners and such intelligence as he shall think useful to the Public Prosecutor for the District, to communicate with and receive Instructions from the Public Prosecutor, to prepare Briefs and attend the Trial, and perform all other Duties of an Attorney for the Prosecution.

Moreover, the district agent on learning of the commission of a crime, whether through the police or otherwise, was to take appropriate steps to ascertain the facts and bring the wrongdoer before the magistrate. On the other hand, the magistrate, in his discretion, was to notify the district agent when a person was brought before him, so that the district agent could attend and examine the witnesses and argue questions of law and fact. The police were charged by the bill with informing the district agent of any crime committed within his district.

Regulations governing the public prosecutions were to be promulgated by an appropriate principal-Secretary of State, i.e., the Home Secretary.

The last important section of the Phillimore bill was one which of necessity-political, traditional, or logical-was to find its way, in one form or another, into almost every scheme for the institution of public prosecutions in England and Wales: the clause saving to private suitors their rights of initiation and conduct of criminal prosecutions: ${ }^{48}$

\footnotetext{
${ }^{40}$ For basic descriptions of the functions of the courts referred to in this paragraph, see JACKson, op. cit. supra note 16 , at 82-100; RAdCliffe \& Cross, The ENGlish LEGAL. SYSTEM C. XVIII (3d ed. r954).

41 [1854] V Parliamentary Papers $57 x$, at $\S \mathrm{X}$.

aId. \& XI.

48 [ 1843 ] V Parliamentary Papers $57 x, \S$ XVIII.

It has been recently been suggested that similar powers should be available to private
} 
Provided that nothing hereinbefore contained shall extend to prevent any Person at his or their own Costs and Charges from preferring a Bill of Indictment before the Grand Jury in any Cases in which by law he or they may now do so....

It went on to exempt from the provisions of the bill any prosecution conducted by order of the Attorney General and prosecutions for common assaults, defamation, nuisance, for stopping-up or nonrepair of roads, and indictments removable by certiorari. ${ }^{44}$ It should be noted that the bill proposed to remedy not only the major problem mentioned by Phillimore in his introduction of the bill-the failure to carry forward prosecutions after the hearings before the magistrate were concluded-but also the difficulty which had most concerned Lord Chief Justice Denman ${ }^{45}$ - the failure to make adequate investigation of crime so that the perpetrator might be brought before the magistrate. This meant that, to a large extent, the proposed new government officials would take over some functions of the police, solicitors, barristers, and most important for the effect on enactment, of magistrates' clerks. ${ }^{48}$ All of these were, to some extent, financially interested in the maintenance of the existent system, and many of them were politically influential. ${ }^{47}$ Moreover, the new bill would reduce the prestige and power of the magistrates and justices of the peace, who even today wield political power, ${ }^{48}$ and at that time were even more potent.

Friends of the bill, or at least of the principle for which the bill stood: the creation of a system of public prosecutions, were not wanting in Commons. A full-scale discussion, not usual on first reading, took place. Sir John Shelley seconded the motion for a first reading. immediately after Phillimore's peroration: ${ }^{9}$

They should not be content with making the Sovereign the nominal prosecutor, but they should recollect that a criminal offense was an offense against society, and society was bound to interfere in administering justice to the offenders.

persons in the United States. See Private Prosecution: A Remedy for District Attormeys" Unzwarranted Inaction, 65 YALE I.J. 209 (1955). The problems which such a change might invoke are evidenced by the materials considered in this paper.

"See p. 547 infra.

${ }^{45}$ See note 28 supra.

${ }^{40} \mathrm{See}$, e.g., 18 L.T. 228, 233 (1852).

${ }^{17}$ One-third of the House of Commons were lawyers. 22 id. at 137 (1853).

${ }^{48}$ See, e.g., Williams, The Proof of Guilt 282 (ig55).

${ }^{10}$ I 30 HANSARD 668 ( 1854 ). 
Mr. Hume: ${ }^{50}$

... fully approved of the measure proposed. . . In Scotland public prosecutors were appointed, and he had long been of the opinion that the practice, if introduced in England, would be attended with great benefit.

And the Attorney General, Sir Alexander John Edmund Cockburn, as he then was, favored "ample discussion," though "he did not think [the bill] was so perfect and complete as may be devised."'51 He took the occasion to state "that the matter was now under the most serious consideration of Her Majesty's Government who feels that the principle of appointing a public prosecutor ought to be adopted." Napier ${ }^{53}$ expressed his approval of appointing a public prosecutor, but he thought "the object ... might be obtained without any statute whatsoever, as in Ireland, where Crown solicitors were appointed upon every circuit to conduct prosecutions." ${ }^{\text {"54 }}$ Many other voices were raised on behalf of the bill, some professing preference for the Irish system over the Scotch, some making the opposite choice. Mr. Stuart Wortley ${ }^{65}$ lamented the absence of a public prosecutor, assigning as primary evils the fact that prosecutions were often brought for revenge or out of personal animosity and the fact that corrupt motives induced settlement of the claims and abandonment of the prosecutions. ${ }^{58}$ Others spoke at length of the evils to be abated, some tersely commended the principle. An occasional doubt was raised about the patronage. But on the motion for the first reading, none spoke against the proposition contained in the bill.

A part of this chorus of approval was found suspect by at least one member of the House. Mr. Phillips, with much prescience, "confessed he was rather alarmed when he heard that a measure of the present character was under the consideration of the Government, as the legal reforms they had undertaken had seldom come to anything." "s? Not so Mr. Phillimore, who, from naiveté or for reasons of rhetoric, alleged

${ }^{50}$ Ibid. Hume had previously indicated his position on the question of public prosecutors in 1851 . See 116 id. 206 .

${ }^{51} 130$ id. at 668 .

${ }^{52} I d$. at 669 .

${ }^{B 8} \mathrm{He}$ had been Lord Derby's Attorney General for Ireland.

I6 I HANSARD 669 (1854).

"He was then Recorder of London and "a most upright and capable judge." The Times, Jan. 2I, 1854, p. 8, col. 6. The office of Recorder of London was then described as "the most to be coveted of all judicial offices, except that of Lord Chief Justice of England." 28 L.T. 93 ( 1856$)$.

so 30 HANSARD 670-7 1 (1854). Cf. his statement in 114 id. at 828 .

${ }^{67}{ }_{30}$ id. at 672 . 
that he "was delighted to hear that the Government intended to take up the matter, and, under these circumstances he would cheerfully resign into the much abler hands of [Cockburn] . . . the conduct of this measure. ..."58 Thus, the bill received its first reading without any discord. The Times optimistically reported.50

The ATtorney-General, who may be supposed to represent the views and feelings of the Government upon the occasion, accepted the introduction of the Bill in a friendly spirit. All that appears to be desired on every side is, that ample discussion should take place upon the details of so important a change. As to the policy of the measure, there is a general agreement.

The bill came on for a second reading on March $19,1854^{80}$ At this time, the pressures seem to have begun to take effect. Cockburn asked Phillimore not to push the bill, stating that he had consulted with the Lord Advocate of Scotland and the Solicitor General for Ireland and he hoped shortly to be able to submit to the Government a scheme for a measure on the subject, with a view of proceeding with it this session. ${ }^{61}$ Phillimore bowed to the wishes of the Attorney General. "After these very explicit assurances ... he would be justified in acceding to [Cockburn's] request." ${ }^{32}$

On May I, I854, Phillimore announced his intention of postponing the second reading once again, the "Attorney General having assured him that it was the intention of Her Majesty's Government to carry the measure this Session which would embody in a great degree the improvements he ... thought necessary to be made in the law, and which he understood would go even still farther with them." ${ }^{313}$ Cockburn was not to be led so easily into an admission by silence. He explained his earlier ambiguous statement to mean "that he was most sedulously occupied in framing a measure which he hoped to present to the House and to be able to carry"; but he was a political realist, and "as to pledging himself to carry a measure of that kind was what he had never done, simply because it would have been folly to do so." He thought the problem would be ensy of solution if an entire "new criminal digest" were to be framed, "but to engraft the notion of public prosecutor on our existing system of criminal jurisdiction was one of the most difficult things the House could possibly attempt to do.... he

\footnotetext{
${ }^{58}$ Ibid. "His hope was that the time was come when, instead of policemen and jail attorneys, homines idonei atque integri causum reipublicas legumque susciperent."

${ }^{50}$ February 15,1854 , p. 10, col. 5. ${ }^{60} 131$ HANSARD 587 (1836).

or Ibid.

${ }^{0 s} I d$. at $x \geq 70$.

${ }^{02} I d$. at 588 .

ot Ibid.
} 
would do his best to carry the measure he had in contemplation." Phillimore apologized for "misunderstanding" the Attorney General and the Phillimore bill was withdrawn. ${ }^{\text {G5 }}$

The plan which Cockburn "had in contemplation" never did take legislative form. His views as expressed before the Select Committee in the following year were suspiciously like the Phillimore bill itself, as was his dissent from the Judicature Commission Report of 1874 . The obvious difficulties which Cockburn saw were political and not technical, as he later confessed. In 1855 , he reported himself as having said to Campbell: "I am at a loss, not in devising a scheme, but in devising such a scheme I think Parliament will adopt."Bs The primary difficulty may have been the composition of the lower house, described during that session by Brougham as being made up "in a great measure of country gentlemen engaged in the administration of justice."187 Time was to reveal the strong and persistent antagonism of "country gentlemen engaged in the administration of justice" to the concept of public prosecutions. Indeed, Sir William Harcourt was to tell the House in I 879 that the "sole reason" why public prosecutions had not been previously sponsored by Parliament was that "it was opposed by the most formidable body except the licensed victualers, in the country. . . . I mean Solicitors."

\section{III}

The I 855 Bill

\section{A. First Reading}

The Government's failure to introduce a bill in the 1854 session did not deter Phillimore. Early in 1855, he again offered a bill of his own to transfer the prosecutorial function to government agencies. ${ }^{69}$ This time, he made specific objection to leaving prosecutions in the hands of magistrates' clerks and the police. He referred to the latter as "a class amongst whom were to be found some of the most hardened and profligate of mankind, and over whom the most incessant vigilance

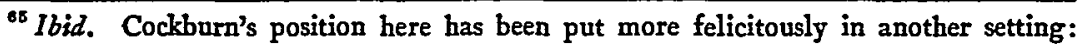
"Like much else in human affairs, its defects are so deeply enmeshed in the system that wholly to disentangle them would quite kill it." L. Hand, in Jorgensen v. York Ice Machinery Co., 160 F.2d 432, 435 (2d Cir.), cert. denied, 332 U.S. 764 (1947).

A similar position had been taken earlier by Sir Robert Peel when he was Home Secretary. See note 23 suppra.

"Minuzes 196.

67 131 HaNSARd 846 (1854); cf. note 47 supra.

0284 HaNSARD $97^{8}\left(188_{4}\right)$.

${ }_{13} 6$ id. at 1651 .
} 
was requisite to prevent flagrant and cruel abuses of their authority. As to the former, "there was evidence that they sometimes recommended commitals because they had a large interest in the fees they would gain by their prosecutions."

The new bill ${ }^{72}$ was not very different from the old one. There were many changes of language and a few of substance. It added a prohibition against the public prosecutor holding "any other Place or Office of Profit whatsoever under the Crown or otherwise."73 Provision was made to put the appointment of district agents into the hands of the Lord Chief Justice rather than the Lord Chancellor, while assistant district agents were to be appointed by a "Majority of Justices at each Petty Session."37 The first of these changes put the patronage in the hands of the highest permanent judicial officer, rather than the cabinet official whose obligations to party might be greater. The second was an offering to the "country gentlemen engaged in the administration of justice." (It should be remembered that the absence of a federal system does not mean an absence of conflict for power between central government and local authority.) The investigative functions which the I854 bill had assigned to district agents were not provided for in the I 855 bill. Finally, the new bill provided that the district agents were to act as attorneys "in serious and important cases" rather than "in all cases."7t5

Cockburn $_{2}$ still Attorney General at this time, answered Phillimore's opening remarks with agreement that "it was very far from his intentions to offer the slightest opposition to the introduction of this Bill"; ${ }^{70}$ but he struck out vehemently against Phillimore's bill as having "appeared to almost every lawyer in the House to be an almost helpless Bill; a more crude specimen of legislation he never saw."'m7 An explanation for this new vehemence is difficult to find, except as an indication of a new Government position which Cockburn described as a willingness to approve a scheme of public prosecutors if the scheme met the problem of "expense" and "of patronage." $\mathrm{He}$ added that public prosecutors would be "entirely new and foreign to the present system."70 These had long been and were to continue for years to be the rallying points of the opposition to public prosecutions. But they certainly were not the personal view of Cockburn, as he was to reveal a few months

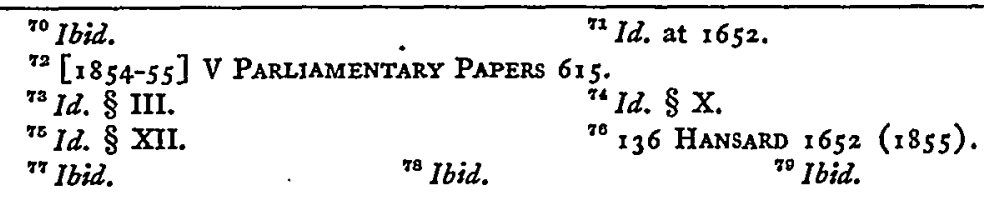


later. They did represent, however, a realization by the Government of the political difficulties of pushing through a measure for public prosecutors at that time.

Cockburn attempted to demonstrate the strength-or the weaknessof his position by recounting the fact that he had taken the question up with the Lord Chief Justice (Campbell) who had said that "during the time he was Attorney General, had again and again directed his attention to the subject, and that, although he was most anxious to devise some scheme, he had failed to devise any scheme that appeared to him to be satisfactory." 80 The Attorney General then resorted to the time-honored legislative cliché, not unfamiliar to other "deliberative bodies," "that the present time was not the proper time for legislation on the subject." 81 Having dealt with the purported reasons for the Government's position, Cockburn retreated to the real reasons. "In the first place, what was to be done . . . with the magistrates clerk? " 82 "He agreed that it would be much better if they were limited to the functions of magistrates' clerks and not allowed to take part in prosecutions; but, then, on the other hand, we should deprive them of considerable emoluments, and then would come the question of compensation."83 And the other real question was not the amount of patronage that would be created, but who was to dispense it. He was opposed to leaving it in the hands of the bench, for they were not responsible to Parliament or the people, they were given to nepotism and favoritism in the distribution of the patronage which they did administer, and it would be a weapon to make the bar subservient. The alternative difficulty was whether the patronage should be left to the central administration or the local communities. Cockburn generously concluded that if Phillimore "could see the way to devise a scheme that would be satisfactory to the House and to the Country he would be glad to see it introduced, and, if it were a scheme fit for adoption, to give it such assistance as lay in his power."84

An Irish member, after getting in his licks against the system which prevailed in Ireland "which had signally failed in securing public confidence in the administration of criminal justice in that country,

${ }^{80}$ Id. at I652. ${ }^{81}$ Ibid. ${ }^{82}$ Id. at 1653 .

${ }^{83}$ Ibid. It is not insignificant that a provision in a bill brought in by the Home Secretary, Sir George Grey, in 1851, to prohibit magistrates' clerks from serving as prosecutors was stricken before the bill became law. See 21 L.T. 20I (1853). The bill, without this provision, became the Expenses of Prosecution Act, 13 \& 14 Vict. c. 35 (1851).

s4 136 HaNSARd 1654 (1855). 
proposed "this subject [be] investigated by a Select Committee: for really, at present, the term 'public prosecutor' was very little understood." ${ }^{386}$ At this point, William Ewart ${ }^{87}$ also pushed for a Select Committee.

A valiant effort was made by Sir Joseph Napier and some of his followers" to get Phillimore "to go on with his Bill, and try to get it passed in a perfect shape before the end of the Session." Bo But the sense of the House, as revealed by several more speeches, was against action prior to commitment to a Select Committee. Phillimore got his first reading. But the die was cast in favor of Select Committee consideration.

\section{B. Brougham's Proposals for Reform of the Criminal Law in the House of Lords}

Before the bill came up for its second reading in the Commons, Brougham spoke to the subject in the House of Lords. He presented a series of resolutions providing for a major revision of the entire system of criminal procedure, including "the extension of a regular police force everywhere,, 900 and making the various clerical offices subject to payment by salary rather than by fee. A major part of his speech was devoted to the adoption of a scheme for public prosecutors: ${ }^{91}$

One of the greatest, if not the greatest, defect of our system, [is] the want of power in the executive government to provide for the execution of the law by putting a criminal procedure in motion. I believe, with the exception of America, if our kinsmen have carried over with them this fault in the English law, but certainly in no other country, is the criminal procedure left to shift for itself, its execution being everybody's business in theory, and so nobody's in fact. . . .

In truth, this plan of leaving the execution of the law to the party injured alone-for I object not to it, if combined with a responsible functionary - came down to us from very ancient and very barbaric times. ... [T] public interest in the peace being preserved, and crimes prevented, never entered into any one's contemplation. Assuredly, if the practice loses itself

${ }^{80} I d$. at 1655 .

${ }^{87}$ Ewart had been a leader in the battle against capital punishment and had been partially successful in 1837 in reducing the number of crimes subject to such punishment. See 7 Will. 4 \& 1 Vict. c. 9 (1837). See Pope-Henessy, Monckton Milnes: The YEARS OF PROMISE 129 (1949).

${ }^{88}$ These included John George who was to be Palmerston's Solicitor General for Ireland and later a Justice of the Queen's Bench.

${ }^{80} \times 36$ HANSARD $1656-57$ (1855). ${ }_{10} 137$ id. at 954 (1855).

${ }^{01}$ Id. at 959, 961-62. See comment in 101 EDiNBurGH REV. 534 (1855), which Brougham may well have written himself. 
in the mists of remote antiquity, it cannot be deemed to claim our respect for its honourable descent. But let us see how it works; how far prosecutions by a competent and responsible officer are more likely to be carefully conducted, and to assure conviction, than when left to anyone that chooses to undertake them. ... [T] [Te acquittals are twice as numerous in England [as in Scotland]; clearly showing the differences between proceedings instituted and conducted by experienced, responsible, professional men, and those left to private individuals.

No one wishes, I believe, to see grand juries dispensed with, although in many cases they might safely be, were there in every case a public prosecutor. ... [E] ven in the case of political offenses, the prevalence of party feelings in troubled times is too likely to warp the grand jury, while the official prosecutor, though under the same influence, is also under the check of responsibility, to which the unknown majority of the grand jury is never subject. ...

He apologized for bringing up the subject in the absence of the Lord Chief Justice, but he felt it necessary to do so in order to avoid the "unnecessary risk of being prevented from laying the whole case before Parliament." "I cannot tell," he said, "how soon I may be summoned from hence." He then proceeded to lay before the House his resolutions. Those pertinent to our subject were as follows: ${ }^{93}$

r. That it is the Duty of the Government to provide effectually for the Execution of the Criminal Law, by the Discovery, the Securing, and the Prosecution of Offenders; ...

6. That the Prosecution of Offenders should be entrusted to an officer appointed by the Government, with such Number of subordinate officers as may be required for conducting Prosecutions in the Counties and larger Towns; but that until such Measure can be adopted, it is expedient to appoint Barristers who shall advise upon and conduct the Prosecutions for the Central Criminal Courts and the Courts of Quarter Sessions of Middlesex and Surrey;

7. That the Public Prosecutor should in all the Graver Cases as the Pleas of the Crown and Forgery, proceed by Bill before the Grand Jury; but in other Cases should at his discretion, be allowed to proceed upon Commitment by a Stipendiary Magistrate, without any Bill found; . . . .

The Government had not yet solidified its position on this issue, or if it had, it had not informed its Chancellor, the lovable but unlearned and ineffective Cranworth. Cranworth announced wholehearted agreement with most of what Brougham had said, but was concerned at the

\footnotetext{
${ }^{22}{ }_{137}$ HaNSARd 973 (1855). ${ }^{93}$ Id. at 973-74.
} 
number of officials who would have to be appointed to carry on the duties of public prosecutions.

Four days after Brougham's proposals had been put to the House, Hatherton asked when he proposed to proceed with them. Brougham responded with a request for a Royal Commission rather than a Select Committee to investigate the subject. He repeated this request again a week later. All he received in response was a compliment from the Chancellor, ${ }^{94}$ together with a refusal on Cranworth's part to commit either himself or the Government to any action, even the submission of the problems to a committee of inquiry.

\section{1855 Bill-Second Reading}

When seeking a second reading of his bill in the Commons a few months later, ${ }^{95}$ Phillimore, too, spoke well, but in vain. He inveighed against leaving prosecutions in the hands of police and solicitors, for "it was the duty of the Government to provide for the pure and exact administration of justice, where the lives and liberties of the subjects were at stake." ${ }^{\text {"96 }}$ He pointed out that the existent system advantaged the rich who could afford to put the machinery into operation over the poor who could not. He suggested that uncertainty of prosecution encouraged crime. He cited the many voices in favor of a system of public prosecutions and rejected the idea that additional expense would be involved.

The Attorney General was not present to hear this eloquence. But the apparent importance to the Government of putting off the bill was emphasized by the fact that, after Ewart had once again asked for a referral to a Select Committee, the Prime Minister himself took the floor to present the Government's position..$^{97}$ Any lingering doubts as

"Id. at 1378 . Cranworth said that Brougham "had, if it were possible, added to his reputation by his Motion on Criminal Procedure." Brougham's reply was that "he desired to have more success and less reputation."

${ }^{95} 138$ id. at 697 (1855).

${ }^{80} I d$. at 698 .

97 "No one resembled less than Lord Palmerston the fancied portrait of an ideal statesman layiug down in his closet plans to be worked out twenty years hence. He was a statesman for the moment. Whatever was not wanted now, whatever was not practicable now, whatever would not take now, he drove quite out of his mind. The pre-requisites of a constitutional statesman have been defined as the powers of a firstrate man, and the creed of a second-rate man.' The saying is harsh but expressive. Lord Palmerston's creed was neyer the creed of the far-seeing philosopher; it was the creed of a sensible and sagacious but still commonplace man. His objects were common objects; what was uncommon was the will with which he pursued them." BAGEhot, Biographical Studies 341-42 (188I).

Cf. "So Lord Palmerston is back again [as Home Secretary], as we had anticipated 
to the fate of the bill disappeared as Palmerston's oleaginous tones sounded the funeral oration. He reported that if Cockburn had been present, he would have agreed to the second reading of the bill and then moved that the subject, not the bill, be referred to a Select Committee: ${ }^{98}$

The subject was well worth the consideration of Parliament. No doubt, the appointment of a public prosecutor, if the details of such a measure would be so arranged as to avoid giving rise to any new inconveniences would be a great advantage. Yet, if, on the one hand, those who, from their position in life, were too poor, or from want of information, too ignorant, successfully to prosecute wrong before a court of justice-if such persons would derive great benefit from the existence of a public prosecutor, and if vexatious proceedings would be to a great extent stopped, yet, on the other hand, it was obvious that a great responsibility and a great discretion must be vested in such a public officer, and that he must operate through a great variety of private agencies, for he could not in his own person conduct all these prosecutions, or even himself decide which should and which should not, be carried out. The questions, therefore, as it appeared to him, although well deserving of serious consideration, would require great preliminary care, information and investigation.

He thereupon moved for a second reading and referral to a Select Committee. If the Prime Minister showed a recognition of the threat to civil liberties which might result from empowering a prosecuting officer with the authority which he had been given in the United States and on the Continent, he did not seem to appreciate that the deficiencies of the existing system might also be dangerous.

After a seconding speech by a back bencher, Sir Frederick Thesiger ${ }^{99}$ made a speech in support of Palmerston's motion. Whatever his intellectual limits, Thesiger was a strong party man, and he followed where his leader led. His speech was a parade of horribles directed rather to Brougham's position in the House of Lords than to the Phillimore proposal: ${ }^{100}$

When it was considered that such a measure would probably be followed by an alteration of the law as to the system of grand juries, that it might lead

last week. The Profession, at least, will rejoice at it, for he was a capital administrator of the law, prompt and decisive, and is bent on a multitude of social reforms, which are of far more practical importance than any organic reform...." 22 L.T. I37 (1853). ${ }_{98} 138$ HANSARD 700-01 (1855).

${ }^{\circ 0}$ Thesiger had been Solicitor General and twice Attorney General. As Baron Chelmsford, he was to occupy the Woolsack.

${ }_{13}^{100} 138$ HANSARD 7OI-02 (1855). 
to the appointment of stipendiary magistrates, that it might render unnecessary the existence of clerks of assizes and clerks of the peace, that it might involve a greater jurisdiction in magistrates and a greater power of preventing cases going to trial-when all these circumstances were taken into consideration, it would be obvious that a most careful examination was necessary before the House adopted any particular measure relating to the question.

It is interesting to note that except for the abolition of the clerks, all these things have come to pass.

Phillimore gracefully agreed that the second reading should be deferred for a month or six weeks. The bill was dead.

\section{The Select Committee}

Whatever the motive to be ascribed to the Government's action in seeking referral to the Committee of the issue of creating a public prosecutions office, no charge of "packing" can be leveled. For the Committee which was nominated was a strong one, including Phillimore, Cockburn, Ewart, Napier, Phillips, Thesiger, Walpole, Miles, Lord Stanley, The Lord Advocate of Scotland, and the Solicitor General for Ireland. On Ewart's motion, Phillimore was named chairman.

Brougham was called by the committee as its first witness. The still very lively "reformer" spoke, as usual, in absolutes. ${ }^{101}$

Nothing can be more ineffectual than the provisions which the law, and the practice under.it, now make ... for the prosecution of offenses. . . An individual is injured by either his person being attacked or by his property being injured, and he is called upon himself to prosecute....

The resulting evils were failures to prosecute, monetary hardship on those who did, and the buying off of prosecutions by those who could afford it. Indeed, just before he was turned out as Lord Chancellor in 1834, he and the Home Secretary had arranged, without the aid of, or need for, legislation, for the Treasury to employ one or more attorneys for the Central Criminal Court and to give them "the preparation and superintendence of prosecutions. This plan was formed upon the precedent which we had set us in some counties in England. . . ."102 He was now in favor of the creation of an office of public prosecutor,

${ }^{102}$ Minutes 1.

${ }^{102} I d$. at 2-3. The county areas referred to were Durham, Northumberland, Chester, and the West Riding of Yorkshire, where "the clerk of the peace singles out one counsel and gives him the general supervision of prosecutions, the preparation of the indictment, the examination of the evidence, and ... the trial." Id. at 3. He also made reference to paid prosecutors-ordinarily solicitors-in borough areas such as Leeds, Liverpool, and Manchester. 
for it would prevent the guilty from escaping punishment and would avoid prosecution of the innocent. The grand jury would be a check on any arbitrary institution of prosecutions by the public prosecutor. And the arbitrary refusal to prosecute by the public prosecutor could be guarded against by permitting private prosecutions in such instances. ${ }^{103}$ The large proportion of acquittals which were taking place by reason of the failure of proper preparation of prosecutions was an inducement to crime. A public prosecutor could replace incompetence with competence, not only in the preparation of the case, but in the preparation of the indictments as well and thereby contribute to certainty of punishment for offenders. He thought that the patronage difficulties could be avoided by making the office a permanent one: ${ }^{104}$

Yes, they ought not to be removable at a moment's warning. The Attorney General must be removable at any moment from the nature of his office, but I am quite clear that those deputies [public prosecutors] . . . ought not to be removable with the Attorney General. If so you will be getting England into the same state in which America is at present. ...

Cockburn took this opportunity to agree, and a colloquy followed which may well be said to have become more typical of the English system of criminal justice than of the American experience: ${ }^{.05}$

[Cockburn:] The first great principle which ought to be inculcated into the mind of every Minister and of every Attorney General with regard to public prosecutors; and with regard to all subordinate agents in the administration of justice, is that politics can have nothing to do with the matter?

[Brougham:] Clearly.

[Cockburn:] And that whosoever has the appointment of the public prosecutor, if the public prosecutor is appointed, should be entirely responsible before Parliament and responsible before his country for the selection of the very best men who can be procured, without any reference whatsoever to any personal or political consideration?

[Brougham:] Certainly, politics have worse, a more corrupting and more dangerous influence than even mere ordinary corruption, for this reason, that they apply to people who are above ordinary corruption, party politics apply to them, and just produce the same effects, and, therefore, they ought not to interfere at all in any branch of the administration of justice.... [I]t should never be understood that these were political offices.

\footnotetext{
${ }^{203}$ Cf. Private Prosecutions: A Remedy for District Attorneys Unzwarranted Inaction, 65 Y YLE L.J. 209 (1955).

208 Minutes 16.

${ }^{105}$ Ibsd.
} 
If these were mere platitudes when they were uttered, they apparently have taken on real meaning since.

Another important witness was Charles Sprengel Greaves, an eminent barrister, with a great deal of experience at the criminal bar. His testimony is of primary interest because so many of his suggestions found their way into the ultimate enactment of 1879 . He, too, listed the existent evils: escape of criminals for want of prosecution; deliberate mismanagement of prosecutions; improper compromise and abandonment of prosecutions; the securing of prosecutions by "low attorneys"; the impropriety of the police extending their duties beyond their "ministerial functions"; the high cost of private prosecutions; and the failure properly to instruct grand juries. He did not, however, see the remedy in the form of the virtual abandonment of private and police prosecutions according to the Phillimore formula, or in the adoption of the system existent in Scotland, Ireland, the United States, or on the Continent. He thought that, public prosecutions were necessary only with regard to "capital cases and cases which clearly from their nature require investigation."106 For the rest, he would have all depositions taken before magistrates returned immediately by the clerks to the public prosecutor, and would prohibit the abandonment or compromise of a private prosecution once initiated, except with the permission of the public prosecutor. He appeared to prefer the continuance of the existent system to the one suggested by Phillimore, and was most insistent on the retention of the right of private prosecutions on leave of court, with the concomitant right to select the prosecuting attorney, who, in turn, could select his own counsel. In all cases, he would permit the prosecutor to choose his own counsel, on the ground that criminal cases provided the proving ground for young barristers. ${ }^{107}$

Lord Chief Justice Campbell, on the other hand, was unaware of failure of prosecutions for want of private prosecutors or for want of money to pay for the prosecutions. He was equally ignorant of any abuses of police prosecutions. But he did say that some cases were poorly "got up" for lack of a public prosecutor. And "the great evil from the want of a public prosecutor in England" was "that the criminal law is often shamefully perverted to mere private purposes."108 The difficulties of public prosecutions, he thought, revolved around the problem of patronage. He much preferred to see such patronage as would be involved in the hands of the Crown to seeing it in the power of the local authorities. But he feared that so much control over business in
${ }^{100}$ Id. at 39 .
${ }^{10 \pi}$ Id. at 47 .
${ }^{208} I d$. at 62 . 
the criminal courts "would be an interference with the independence of the bar."109 Campbell did not believe that the proposed system would involve any additional costs, except for the initial outlay by the Crown. He was forceful about one point::110

I think myself that it is the privilege which belongs to every Englishman, and of which they ought not to be deprived if it is properly guarded, to put the criminal law in force by their own authority. I should not like to see a system established here that there should be no prosecution unless instituted by a public functionary; but I think it is most essential, and I have recommended it to the present Attorney General, and, speaking most respectfully, I would recommend it to the Members of the House of Commons, to consider whether there should not be some check put upon prosecutions for perjury and conspiracy, and for keeping these gaming houses and so on. I think it would be well if these prosecutions could not be instituted unless with the sanction of a public responsible functionary.

On the other hand, he had recognized the political difficulties in pushing a more extensive system of prosecutions by public prosecutors. $\mathrm{He}$ thought "it would be a very bold thing in a Government to bring it forward at present; if I were still Attorney General I should hardly have the courage to recommend it."111

At this stage, however, the Attorney General was prepared to be bold, and in his testimony before the Select Committee, he made it quite clear that he did not see the same difficulties which he had announced on the floor of the House of Commons to be those which were troubling the Government. $\mathrm{He}$, too, went through an impressive list of problems resulting from the existence of the system of exclusively private prosecutions: the inability of the poor to put the machinery of criminal justice into operation; poor preparation of cases; the maintenance of frivolous prosecutions; collusion by which defendants bought off prosecutions; and ${ }^{112}$

${ }^{100}$ Ibid.

${ }^{120} I d$. at 65 .

${ }^{111}$ Id. at 62. Whatever his other attributes, it must be noted that courage was not one of the Lord Chief Justice's outstanding qualities. "It has often been said that Lord Campbell is not fond. of opposing public opinion; that he loves rather to meet it halfway; that he had little of that courage, the inost rare and the most necessary quality in modern public life, which can brave the assaults of the newspapers, and quietly outlive a popular outcry. . . . We have heard it stated that though he is an upright and painstaking judge, yet that it would be better to be tried by some one else if a very great many people wished us to be hanged, and said so in a vcry great number of newspapers. He would give us fair play, it is said, yet in his inmost soul he would think all those people ought to be satisfied." I 7 THE ECoNOMIST 757 (1859).

${ }^{122}$ Minutes 185. 
a large class of cases in which criminal justice is resorted to for the mere purpose of enforcing civil rights. ... In all these cases, supposing the prosecutions honest ones, and that offenses have really been committed, it is desirable that the parties who have been guilty of conspiracy or perjury, or ony offense of that nature, should not escape by merely making a pecuniary arrangement with the prosecutor.

He went on to condemn police prosecutions: ${ }^{113}$

I will add another, to my mind, very serious evil which I have observed very often myself, sitting as recorder, and that is the manner in which policemen mix themselves up with the prosecutions. I must say I think it is a great scandal (to use no milder term) to see a case brought into court by one of the inferior ministers of the law such as a policeman. I do not think it consistent with the proper administration of public justice, in a great country like this, that you should have a subordinate officer, who is merely the keeper of the prisoner, clothing himself with the function of a public prosecutor. I think it has, also, this further mischievous effect. I have observed often, and have had occasion to notice it in court, how policemen become over-zealous in the conduct of prosecutions. I can quite account for it now [that $I$ know] that the promotion of policemen is made to depend upon the prosecutions which they successfully conduct.

$\mathrm{He}$, therefore, favored supervision of criminal investigation by a man of ${ }^{114}$

higher intelligence... who should see that the men employed for such purposes do not exceed their duty; and I think it ought to be done by policemen who are not mixed up with the particular case, who are not the persons who apprehended the prisoner, or who are to give evidence on the trial, but they should be men employed merely for that particular purpose.

(One thinks that Cockburn would be pleased with the various C.I.D. branches in the English police forces.)

After raking the police over the coals, ${ }^{110}$ Cockburn turned on the legal professions for some of their actions under the existent system. In so doing, he stated a credo which present-day lawyers would do well to follow: ${ }^{116}$

\footnotetext{
${ }^{213} \mathrm{Id}$. at 186 . This continued to be a problem throughout the history of this legislation.

114 Minutes 187 .

${ }^{115}$ Interestingly enough, the one Chief Constable who testified objected to the binding over to prosecute of policemen by the magistrates.

${ }^{110} \mathrm{Id}$. at $\mathrm{I} 88$.
} 
I have often felt that where an attorney is employed by a private prosecutor, for the purpose of bringing a case to trial, the attorney, considers it too much a matter of professional importance to himself. I have known instances, on circuit, in which, as counsel for the prosecution, I have found it my duty to moderate the over-zealous and inordinate desire of the prosecuting attorney to get a conviction. . . Nay, I am bound to add, that I think sometimes even counsel themselves are not altogether free from this kind of desire to get a conviction, because it gives them professional triumph, after which they are likely to be employed in other cases; it places them in a position of superiority to their competitors and rivals. ${ }^{117}$

Now I think if you had a prosecutor permanently established, who should hold a high position, in which it would be his duty to see public justice administered, in which he would exercise a sort of combined function of advocate and of magistrate, all that he would feel himself bound to do, and beyond which he would feel himself bound not to do, would be to see that if in his internal conviction there was a case of crime, the prosecution of that crime should be carried to a successful conclusion; but if he had the slightest doubt or hesitation about it, he would be bound to place before the court and jury all that could be made in favour of the prisoner, as well as all that could be made against him.

Lord Stanley then asked, "Would there not be equally a desire to succeed in a conviction, in order to avoid damaging his professional reputation, would not that desire exist equally in an officer conducting a prosecution on the part of the public, as it does now on the part of the counsel conducting the prosecution?"118 To which Cockburn replied, "Hardly so, and for this reason, he would have achieved his position and would have no competition to apprehend." He went on to say that given the proper remuneration, there would be no diffculty in getting men of the highest caliber to undertake the jobs "although these offices led to nothing higher."

Cockburn proceeded to announce what was full support for the Phillimore type plan for public prosecutions, though like Bentham, he would leave the right to prosecute privately in those instances in which the public prosecutor failed to act. He was opposed to magistrates' clerks carrying on prosecutions; he would "unhesitatingly put appointments in the Home Department"; he failed to see any reason why the bar should be made subservient by such patronage in the Crown, point-

${ }^{117}$ That the situation had not changed a decade later, see I L.J. x43-44 (x866).

${ }^{218}$ Minutes 188.

${ }^{210}$ Ibid. This proposal ought to be canvassed by American jurisdictions, where the prosecutor's office is a stepping stone to higher political or judicial posts. 
ing to Ireland as an example; and he thought expense "a secondary consideration" and even so, did not think that the proposed system would add to the total cost of prosecutions. It hardly sounded as if Cockburn the witness before the Committee was the same Cockburn who had spoken of these problems on the floor of the House of Commons. ${ }^{120}$

After hearing Cockburn's testimony, Phillips put it to the AttorneyGeneral:121

[Q.] Do you think that any Bill which proposes so great an alteration of the law as regards public prosecutions, as this Bill does, should be introduced by the Government?

[A.] I do; and I am bound to say, that when my honourable and learned friend first introduced his Bill, he was good enough to withdraw it upon the assurance which I gave that Her Majesty's Government would take the matter into serious consideration, with a view to making it a Government question; ... I considered it for a year, and could frame no scheme that $I$ did not think would be open to great opposition and I told [Phillimore] that I was convinced that nothing but a thorough investigation of the subject before the Committee would open the minds of the people to the necessity for a change; that it would require thorough investigation to let in daylight upon it, and that when that had been done, I thought that if the Committee should come to the conclusion that a change was desirable it would be a thing which the Government might well take up; whereas if the Government took it up before there had been such an inquiry it would only end in failure.

[Q.] The Lord Chief Justice stated that there was such great objections to the scheme at the time when he was Attorney General that he thought them insurmountable; do you think such objections exist at the present time?

[A.] I think not. . .

In addition to these important witnesses, the Committee examined many others at length. Lord Moncrief testified about the system existent in Scotland, ${ }^{122}$ and the Solicitor General for Ireland expounded on the Irish system. The existing systems in York, Leeds, ${ }^{123}$ Manchester,

\footnotetext{
${ }^{120}$ See p. 506 supra.

${ }^{121}$ Minutes 196.

${ }^{122}$ In 1860 , the Lord Advocate delivered an address applauding public prosecutions as conducted in Scotland, but he recognized that "a public prosecutor in an arbitrary state is very dangerous to the liberties of the people." 4 Sol. J. 893, 896 (1860).

${ }^{123}$ The system at Leeds-in effect since 1842 -was later attacked. The contention was that the "right to prosecute rested neither in the magistrate nor in any other person but the person aggrieved or injured." ${ }_{4}$ SoL. J. 650 (1860). The system survived the attack which was, however, a vehement one: "It is, we think, high time that a system which is at once so unjust to the attorneys, so detrimental to the interest of the public, and so detrimental to the bar, should be abolished." 5 id. at 155 (1861). Cf. 35 L.T. 175 (1860).
} 
and Liverpool were also presented in detail to the Committee. ${ }^{124}$ Even the American system, as exemplified by public prosecutions in New York City, was brought to their attention.

The only sustained opposition came from those who were eager to give to the magistrates' clerks the duties of prosecuting attorneys. Among these was the Recorder of London, Stuart Wortley, and R. M. Straight, then Deputy Clerk of Assize on the Home Circuit and Clerk of the Arraigns of the Central Criminal Court. Similar testimony was secured from George Leeman, Clerk of the Peace for the East Riding of Yorkshire, Henry Avory, Clerk of Indictments on the Home Circuit, and Horatio Waddington, Under Secretary of State for the Home Department. Waddington's testimony may have been more revealing of the Government's position than was the Attorney General's.

Sir Joseph Napier contributed the gratuitous warning: "In introducing a new system great care should be taken in England to avoid coming too suddenly in collision with what people have been accustomed to."125 Of sudden change, he need have had no fear.

The resulting committee report was short: ${ }^{\mathbf{1 2 0}}$

Considering, however, the advanced period of the Session at which the last portion of the Evidence was received, and the absence from town of several Members of the Committee, Your Committee think it most expedient to content themselves for the present with presenting to the House the Evidence they have collected. They recommend that they should be permitted to resume their labours at the commencement of the next Session.

\section{E. The Select Committee Report}

The Commons did, however, receive a report in the next session which made recommendations not dissimilar to those which had been twice sponsored by Phillimore. ${ }^{127}$ In substance, the report recommended a hierarchy consisting of "district agents" to be appointed one for each district, the district to approximate county lines as closely as possible; "advisory counsel," one for each judicial circuit; and the Attorney General. The district agents were to be subject to the control of the advisory counsel, and the latter were to be under the direction of the Attorney General. The district agents, experienced solicitors, were to be appointed-and presumably removable-by the Home Sec-

\footnotetext{
${ }^{124}$ Systems similar to those described to the Select Committee were in effect in other localities in England. See, e.g., 3x L.T. 186 (1858); 32 id. 185 (1859).

${ }^{228} \mathrm{Id}$. at 147 .

120 [1854-55] XII Parliamentary Papers iii.

227 [ 1856$]$ VII Parliamentary Papers 347.
} 
retary, were to be full-time salaried employees, whose duties were to be the preparation and conduct of "prosecutions through the stages preliminary to trial."128 They were to be relieved, however, of the task of appearing before the magistrate in any instance where "the case is plain and the evidence complete." In In cases of "difficult and complicated character," it was expected that they would call on advisory counsel for "advice and assistance."130 In any event, advisory counsel were to be free to impose their advice and assistance upon the district agents. A similar relationship was to exist between the experienced barristers who were to be appointed as advisory counsel and the Attorney General. In their case, however, they were to be only part-time employees, paid by salary, to be appointed by the Attorney General but removable only by the concurrent decision of the Attorney General and the Home Secretary.

In order to preserve the "independence of the Bar" and the use of the criminal courts as the proving grounds for young barristers, in ordinary cases, both at sessions and at the assizes, "the choice of counsel should be left to the district agents ... according to the best opinions which the agents shall be able to form of their competency and fitness."131 In the extraordinary cases in which leading counsel would ordinarily be employed, the appropriate advisory counsel for the circuit was to act as trial counsel ex officio. Such counsel as were retained by the district agents were to be paid by fee.

On the very touchy subject of private prosecutions, the Committee devised a scheme: $:^{132}$

Your Committee would not, however, go the length of advising that individuals instituting prosecutions should be prohibited from employing their own attorneys and counsel, and be compelled to report exclusively to the Public Prosecutor. We think it should be left open to the private prosecutor to pursue the ordinary course, as at present practised; but with a view to prevent the compromises which the evidence we have taken shows are sometimes resorted to for purpose of private interests, and to assure the effective administration of justice, we would make it compulsory on an attorney employed to conduct a private prosecution, to give notice to the district agent of his intention to prefer an indictment, and would give the latter authority

\footnotetext{
${ }^{128}$ Id. at 355 . ${ }^{180}$ Ibid.

${ }^{230}$ Ibid.

${ }^{231}$ Ibid. The Attorney General was charged with seeing that "the selection of counsel should be honestly and conscientiously made with a view to the public service, and not from any desire to promote the interest of particular individuals." Ibid.

${ }^{232} I d$. at 356 .
} 
to intervene, and, if necessary, to apply to the court for leave to take up the prosecution and conduct it to its close. With the same object we recommend that in cases where the defendant had not been previously taken before a magistrate, no indictment shall be allowed to be preferred without the consent in writing of the Attorney-General having been first obtained; that in all such cases it shall be competent for the Attorney-General in any stage of the proceedings to intervene by himself or by his advisory counsel for the district; and that no prosecution once commenced shall be abandoned without the consent of the Attorney-General or such counsel on his behalf. And no verdict for the defendant, taken by consent of the prosecutor, shall, in such a prosecution, enable the defendant to plead autrefois acquit, unless the Attorney-General or his counsel shall have given his assent thereto.

Provision was also made for the magistrates to transmit the necessary information and documents to the district agent and to call on the district agent's participation where the magistrate should deem it necessary.

It will be seen that at the end of the first stage of this legislative history-for no further action was to be forthcoming in Parliament for some time-the difficult questions were to be resolved by restricting the bar as little as possible; by choosing the central government rather than the local authorities for the dispensation of patronage, at the same time putting that patronage in the hands of the executive rather than the judiciary; by effectively eliminating the magistrates' clerks from participating in prosecutions; by restricting police participation in prosecutions to the role of investigator and witness rather than prosecutor; by limiting the role of the solicitor to those cases in which a client retains him as prosecuting attorney; and by eliminating the power of defendants to buy their way out of prosecutions.

\section{IV}

\section{Parliamentary Hiatus i $855-70$}

The silence of Parliament might be explained by the absence therein of an advocate for public prosecutions. Phillimore was not returned to the next Parliament; Cockburn was appointed Chief Justice of Common Pleas, from where he was to be appointed Chief Justice of Queen's Bench; in the House of Lords, Brougham remained strangely silent on this point. ${ }^{133}$ And the Report, which aroused widespread approval, was buried in the archives without benefit of ceremony.

\footnotetext{
183 "Brougham was himself a better beginner than finisher." CARR, A VICTORIAN LAW REFormer's CoRrespondence io (1955). Cf. Bagehot, op. cit. supra note 97,
} 
Charles Sprengel Greaves, however, did not approve of the Select Committee Report and had an opportunity to say so in a report he made to the Lord Chancellor. ${ }^{134}$

Greaves dealt with the administration of the criminal law in general and seems to have been inspired primarily by the Brougham resolutions in the Lords. ${ }^{135}$ But much of his report was concerned with the appointment of officials in the nature of public prosecutors. He agreed that such officials were needed, but he would assign them duties different from those thought necessary by the Select Committee. Their efforts, he thought, should be especially directed to the period preceding the magistrate's hearing, for it was the deficiency in police operation that most concerned him. Thus, he would assign these officials the duties of supervising the investigation into the existence of crime and the arrest of the perpetrators thereof; they would supervise the police and conduct the proceedings before the magistrates. It is to be noted that the Select Committee proposal would leave these functions outside the control of the district agents, except that in important cases, they might conduct the hearings before the magistrates. Greaves would also have these officials charged with reading the depositions taken before the magistrates and instructing the attorneys for the prosecution with regard thereto. These attorneys would be appointed by the aggrieved party where such person wanted to press the prosecution, and by the magistrates where no aggrieved party came forward for this purpose. They would also advise the magistrates, where necessary, and attend the grand jury proceedings, and thus be in a position to prevent frivolous prosecutions as well as to advance proper ones. ${ }^{138}$

As Greaves pointed out, his officials could be superimposed on the existent system, with little change in practice, at least in so far as the clerks, the solicitors, and the bar were concerned. Thus, he might eliminate the most potent opposition to legislation on the subject. So far as patronage was concerned, he would place the appointments of

at 73: "The completed, elaborated reforms by which Lord Brougham will be known to posterity are few, are nothing in comparison with his power, his industry, and his opportunities. There is nothing, perhaps, for which he is so ill qualified. The bold vehement man who exposes an abuse has rarely the skilful, painful, dissecting power which expunges it. ..." But Brougham must be credited with efforts outside of Parliament to achieve his objective. See, e.g., speech before Bradford Social Science Congress, cited in 4 Sol. J. 26 ( 1859 ).

${ }_{134}$ A Report on Criminal Procedure to the Lord Chancellor (1856) [hereinafter referred to as REPORT].

${ }^{135}$ See p. 509 supra.

${ }^{136}$ REPORT 52-53. . 
these officers in the Crown, and the expense item was cared for by charging the district in which the official was to act for his services. These services, it was expected, would occupy the full time of the appointee.

He forcefully set forth his objections to the Select Committee proposal in this report. The extensive system therein suggested was unnecessary, he said. "Where prosecutions fail in court, they fail either through the want of proper preliminary proceedings, or through the non-existence of sufficient evidence, ${ }^{\prime 137}$ and not by reason of the conduct of the proceedings themselves. Moreover, the cases on circuit were now conducted "by some of the most rising young men" who have the zeal which would be lacking in permanent officials. No first-rate counsel, he suggested, could be secured to accept the post of "advisory counsel." Moreover, it would discourage study of the criminal law, for the major part of the two legal professions would be excluded from its practice. Leading criminal counsel would lose their present business and leading counsel generally would stop attending the circuits. ${ }^{138}$

His position that leading counsel would not accept the posts available under the Select Committee proposal was a contradiction of his own suggestion that an officer to be appointed under the Greaves' program "must be a person of great intelligence and activity, and of considerable experience in criminal prosecutions, otherwise his duties will not be adequately performed. . . ."139 $\mathrm{He}$ attempted to buttress his strongest argument that this proposal would accomplish the necessary ends with the least interference with the existent system: ${ }^{140}$

In considering this question it should also be remembered that it is a very different thing to determine what, in the first instance, would be the best to be done, from determining what is best to be done after a certain system has long been in operation, and the public having been impressed with the idea of their right to conduct prosecutions, might, in England, be indignant at that right being taken away; whilst prosecutors in Scotland may feel no annoyance at a public prosecutor, because in each country the public are impressed with the opinion that such system is right, and have been bred up from their childhood with such system in operation.

This would seem to be somewhat of a red herring, if that discredited phrase may still be used, since none of the existent proposals suggested the elimination of private prosecutions. $\mathrm{He}$ did, however, make a

\footnotetext{
${ }^{187} I d$. at 56.

${ }^{288}$ This argument was repeatedly urged. See, e.g., 50 L.T. 374 (1871).

${ }^{239}$ REPORT 57.

${ }^{240}$ Ibid.
} 
point reflective of the attitude of many people toward a powerful central government. "Juries are no friends of prosecutions carried on by the Government; and it is extremely questionable whether they would look with even minds upon a public prosecutor."141

Parliament, despite a promise by the Home Secretary to frame a bill during the recess following the 1856 session, ${ }^{142}$ remained virtually silent on the subject of public prosecutors from the time of the filing of the Select Committee Report in 1856 until 1870 . This inactivity was not due to want of agitation outside of Parliament. ${ }^{143}$ And, while it must be recognized that this was a period of crisis for England no less than for the United States, there is no indication that the critical nature of events was responsible for the failure of interest in the subject on the part of the Government. Time was found for legislation of no more pressing nature. Nor had there been a noticeable improvement in the existent system of prosecutions. ${ }^{144}$ Prosecutions which were nothing short of blackmail continued. ${ }^{145}$ And the police continued their contributions to the miscarriage of justice. ${ }^{146}$

The case for the opposition was best put, perhaps, by the Law Times, which moved from a position of support, ${ }^{147}$ to one of doubt, ${ }^{148}$ and then to a consideration of evils which might well flow from such a system, which suggested opposition. ${ }^{140}$ Among other things, the Law

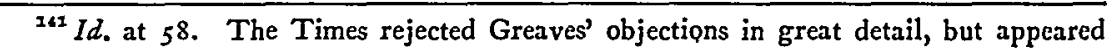
willing to take any plan which provided for public prosecutions. The Times, Aug. 26, I 856, p. 6, col. 3 .

${ }_{142}$ See 27 L.T. 135 (1856).

${ }^{143}$ For example, a jury at the Central Criminal Court memorialized the Recorder with a request for the appointment of a public prosecutor. 44 L.T. 466 (1868). The nonlegal journals continued their clamor. See, e.g., 127 Q. REv. 44 (1868); 35 Westminster Rev. 84 (1869); Times, Mar. 12, 1868, p. 12, col. 2 ; id. July 7, 1869, p. 9, col. 5. See note 153 infra.

1"4 Edwin Chadwick, close friend and disciple of Bentham, who had spent his life in the attainment of reforms for which he was belatedly knighted, see Richandson, The HeAlth of Nations (1889), took up the cause. 4 L.J. 685-86 (1869). See also 8 Sol. J. 4 I (I863); 9 id. 907 (1865). The Trades Unions Commissioners had suggested the need of public prosecutors for the protection of the laboring classes. 4 L.J. 685-86; see also 46 L.T. 164 (1869). Chadwick asserted that the law officers were opposed to public prosecutions lest it mean that they have to surrender their private practices to attend to such prosecutions. See also Times, March 8, 1872, p. 6, col. 6 .

${ }^{145}$ See 8 Sol. J. 4 I (1863); MacKinnon, Grand Larceny, Being the Trial of Jane Leigh Perrot, Aunt of Jane Austen ( 1937 ).

${ }^{148} 9$ Sol. J. 907 (1865). See also, on other police failures, 35 L.T. 318 (1860); 35 WESTMINSTER REV. 84 ( $186 \dot{9}^{\circ}$ ).

${ }^{147}$ See 44 L.T. 466 (1868); 47 id. at I5s (1869).

${ }^{148} 47 \mathrm{id}$. at I 96 (1869).

${ }^{160} \mathrm{Id}$. at $278(1869)$. 
Times suggested that the office would be subject to insistent pressures from the press. ${ }^{160}$

Shortly thereafter, in another editorial, the same publication considered the question again: ${ }^{151}$

This question will be formally mooted in the next Parliament. There is much to be said on both sides. . . . Experience is not altogether in its favour. ... Undoubtedly it may be made the instrument of a tyrannical Government, and although, so long as our present institutions endure, there is little danger to individual liberty from official power, it must be remembered that we hold that liberty by a very frail tenure. Democracy is rapidly advancing, and where Democracy is, individual liberty perishes. The public prosecutor of a democratic despotism would be a terrible engine. Forethought would counsel caution in doing anything under present circumstances that would increase the power of the Government, which a very small advance in the direction to which it is marching, will convert into the most intolerable and intolerant of all tyrannies-the tyrannies of numbers over intelligence and property....

V

The I 870 BILL

\section{A. First and Second Readings}

Whether for the reason advanced by Edwin Chadwick, ${ }^{152}$ or those put forth by the Law Times, or some other, ${ }^{163}$ when a new bill was introduced in Commons on February 22, $1870,{ }^{154}$ the Government was not the author of it. A private bill was introduced by Vernon Harcourt $^{155}$ after the Government indicated that it would not do so. ${ }^{168}$ The

${ }^{100}$ The reality of this danger is pointed up by Mr. Justice Frankfurter's position in Maryland v. Baltimore Radio Show, 338 U.S. 912 (1950). Compare the English cases cited there at 92I-36, with the United States Supreme Court's apparent willingness to subordinate the right to a fair trial to the. freedom of the press to publish inflamatory comments. Bridges v. California, 314 U.S. 252 (194I); Pennekamp v. Florida, 328 U.S. 331 (1946); Craig v. Harney, 331 U.S. 367 (1947).

${ }^{161} 47$ L.T. 350 (1869).

102 See note 144 supra.

${ }^{263}$ The Economist, a supporter of public prosecutions, suggested that public "opinion is gradually coming round to recognize the necessity of such an appointment." 26 ECONOMIST 470 (1868). It endorsed the suggestion that the "magistrate's clerk of each [petty sessional division] should act as deputy prosecutor for that division." The plan had been detailed in Criminal Procedure-Public Prosecutions, 30 LAw Magazine 347 (1863); Stuart, Criminal Prosecutions, 35 id. at 93 (1864); Greaves, Criminal Procedure, 31 LAw MAgaziNe 165 (1866); 32 id. at 191 (1867); 33 id. at 30 (1867). 284200 HANSARD 684 ( 1870 ).

${ }^{268} \mathrm{He}$ was later to wield great power as Solicitor General, Home Secretary, Chancellor of the Exchequer, and Leader of the House of Commons. 
other names on the bill were those of Messrs. Eykyn and Rathbone and of Viscount Sandon.

The new bill made some bows in the direction of political expediency and economy, but they were not enough. In substance, the measure called for a public prosecutor to be appointed for each district and gave the power to appoint a counsel for each of the existent circuits. The public prosecutor was to be an attorney or solicitor of at least ten years' standing who was to be appointed by the Secretary of State. The Secretary of State was authorized to secure the advice of the local government for the district for which the appointment was to be made. Though his term of office was to be five years, subject to reappointment, the public prosecutor could be removed at any time. ${ }^{167}$ These provisions suggested an attempt to assuage the local officials by giving them a hand in the patronage and, at the same time, assuring that it could be treated as patronage by providing for removal of incumbents. ${ }^{168}$

This official's duties were "to institute and conduct prosecutions for indictable offenses committed or alleged to have been committed within his district,"169 subject to certain limitations. He was to be free to institute or intervene in a prosecution for a felony or misdemeanor which fell in the class of indictable offenses where costs were already allowed to prosecutors by law. Where costs were not so allowed, however, he could intervene in a prosecution already begun, but he could not initiate such action except by direction of the court, a judge, a Secretary of State, or the Attorney General. Nor could he participate in a hearing on information, except at the request of the judge. It may be assumed from these provisions that the public prosecutor was to be entitled to costs in the same manner as private prosecutors, except that he was not entitled to receive anything for the time of his staff.

Where the public prosecutor did initiate a prosecution or intervene in one, the bill charged him with taking all measures necessary for collection and preparation of evidence, for preparing and presenting the indictment, and for instructing counsel. In addition to providing for the transmission to the public prosecutor of information about the commission of indictable offenses, proceedings taken with regard to

\footnotetext{
${ }^{150}$ See the Times, Feb. 19, 1870, p. 6, col. 6.

${ }^{187}$ For an argument in favor of life tenure, see 5 L.J. 295 (1870); see other comments in correspondence, $i d$. at $28 \mathrm{r}, 3 \mathrm{r} 4$.

${ }^{158}$ Id. at 265 .

${ }^{250} \S 5$. For a current definition of "indictable offences," see Cross \& JoNES, AN Introduction to Criminal Law (3d ed. I953).
} 
them, and copies of the depositions, the bill prohibited a private prosecutor from instituting grand jury proceedings until after notice to the public prosecutor. Similarly, the public prosecutor was given power to require a private prosecutor to lay an information before a justice before instituting a proceeding.

To assure the independence of the public prosecutor, the bill provided that he was to be salaried, that his salary and expenses were to be paid by the Government, that an office and staff were also to be provided, and that both he and his partners were not to hold office as a clerk of the peace or a clerk to a justice and were not to be concerned in any way with any criminal cases prosecuted in or arising in his district except as public prosecutor.

A circuit counsel was authorized for each of the existing circuits. He was to be a barrister of not less than ten years' standing. His salary was to be fixed, and he was subject to removal at the pleasure of the Government. No fixed term of office was provided. Like his subordinate, he was barred from advising or participating "in any criminal prosecution within the circuit for which he is appointed,"160 except to carry out his official duties. These included the obligation to advise the public prosecutors within his circuit on any matter in which they sought advice "or in which he may otherwise see reason to interfere."1161 He was authorized to refer any matter to the Attorney General for instruction and was required to do so where the Attorney General so requested. At the top of the hierarchy was the Attorney General, who could instruct the public prosecutor or the circuit counsel and was authorized to require that any case be tried "by or on behalf of $\mathrm{Her}$ Majesty's Treasury."162

So far as private prosecutions were concerned, in addition to the limitations already discussed, the bill provided that in any case in which the public prosecutor assumed control of the prosecution, no one else could participate in it, except as a witness, unless the public prosecutor granted permission to the private individual to associate himself in the prosecution. The private prosecutor was also protected by requiring the public prosecutor to inform him in the event of the latter's withdrawal from the case, in which event the private prosecutor was free to continue the action, on condition that he could not then be granted costs. On the other hand, a public prosecutor could not withdraw from a

\footnotetext{
${ }^{100} \S \mathrm{x} 6$.

201 \& $8(\mathrm{I})$.

$102 \S 9$.
} 
prosecution unless he notified his circuit counsel of his proposed withdrawal and established his reasons for taking such action.

Two saving clauses were inserted in the bill. The first was the usual one, saving to private suitors the right to initiate and maintain actions "where the public prosecutor does not institute or intervene in a prosecution."163 The second, which hinted at the existence of a not unusual bureaucratic jealousy, saved to the Solicitor of the Treasury the control over all prosecutions for violation "of the statutes relating to Her Majesty's revenue of excise or customs, stamps, taxes or post office."164 The Treasury Solicitor was authorized, however, to make use of the services of the public prosecutors and circuit counsel. Provision was made for the Government to promulgate the necessary regulations to effectuate the statute.

The bill thus presented seemed to avoid stepping on the toes of the bar, for it did not provide for a monopolization of the trial of criminal cases; it sought to placate the local authorities by giving them a say in the appointment of public prosecutors-on the other hand, it eliminated the tenure of office of the appointees; it limited additional expenses by restricting the major part of the public prosecutors' work to criminal actions in which costs were otherwise assessable; it tread lightly on police toes by rejecting the original suggestions of putting the investigating process in the control of the public prosecutor. It did not, however, give the prosecuting authority to justices' clerks or clerks of the peace and thus threatened them, along with other solicitors, with the loss of a substantial amount of business.

The first reading took place on February 22, 1870, without debate. Mr. Eykyn moved the second reading on May 4, too late in the session to give any real hope of passage. In support of his motion, he relied primarily on the evidence developed by the 1855 Select Committee and especially on the views of Brougham and Cockburn, who was now Lord Chief Justice. He pointed out that "so much was the want of a public prosecutor felt, that in many places in the North some similar institution was maintained by subscription. ${ }^{3165} \mathrm{He}$ hoped the Government

\footnotetext{
${ }^{203} \S 10(4)$ : "Nothing in this Act shall be construed to prevent any private prosecutor from prosecuting in all respects as if this Act had not been passed in any case where the public prosecutor does not institute or intervene in the prosecution."

${ }_{184} \S 22$. The bill was summarized with approval in I4 SoL. J. 388 (1870). The editors were most enthusiastic about its eventual success. "It seems likely that before many years are over we shall really have something in the nature of a public prosecutor."

${ }^{105}$ These organizations for private prosecutions continue in existence today, frequently as dining clubs. Sir Theobald Mathew, the Director of Public Prosecutions, is
} 
would not oppose the second reading of the bill, but if there were any of the details in it to which they objected, they would amend it in committee. ${ }^{168}$

The Attorney General, Sir Robert Collier, who was shortly to be appointed a Common Pleas judge, so that he might have the proper stepping stone to the Privy Council, spoke for the Government which "approved the principle of the Bill, though in so saying, of course, he did not commit either himself or his colleagues to all of its details." Unfortunately, for some unstated reasons, "he had not anticipated that any discussion would arise with regard to them."167 $\mathrm{He}$ concurred with Richard Assheton-Cross and Joseph Warner Henley, who suggested the appointment of another Select Committee to deal with the subject: ${ }^{108}$

In its leading features this Bill seems to carry out the recommendations of the Committee of I 855, which had reported on the subject; but as there were some deviations from the recommendations, the Bill might be properly considered by a Select Committee. . . . Subject to certain alterations which he had foreshadowed in the suggestions already offered, he was prepared to assent to the Bill on behalf of the Government.

Eykyn consented to the reference to the Select Committee, and, after a second reading, the bill was committed. In the eyes of some contemporary observers, the reference augured well for the bill. ${ }^{169}$ There was some suggestion that solicitors had lost interest in minor prosecutions at least. ${ }^{170}$

gathering material about them in anticipation of publishing a history of their operations. That these groups were numerous at this time is attested by the inclusion in the Law Times for 1844 of "Forms for Rules of Association for Apprehending and Prosecuting Felons and Other Offenders." 2 L.T. 392.

188201 HANSARD 241 (1870).

${ }^{167} \mathrm{Id}$. at 244. Outside of Parliament, there was some favorable reaction from bench and bar. "At the Gloucester Quarter Sessions, Mr. Serjeant Pullen delivered a long address in favor of the introduction of public prosecution." 5 I.J. 32 (1870); see id. at $265,281,295,314$. The reaction of the Law JourNal was somewhat insular: "Mr. Serjeant Pullen says that we are behind other nations; but we should be sorry to change our system of justice for the continental system which includes the institution of public prosecutors. If our machinery is less symmetrical in theory, it is far more effective in practice." Id. at 32.

${ }^{188}$ Id. at 245. A Mr. Hibbert approved the Bill though he "had always thought that the advantages of our system of administration of the criminal law was, that the Government had as little as possible to do with it." Ibid.

${ }^{160}$ See 14 Sol. J. 569 (1870).

${ }^{170} \mathrm{Ibid}_{\text {; }}$ II I.J. $65 \mathrm{I}(1876)$. Nor was this situation a new one. See 2 I L.T. 9 $(1853)$. 


\section{B. The 1870 Select Committee}

While the bill was in the hands of this Committee, Sir David Wedderburn moved for the appointment of another Select Committee "to inquire into the present system of conducting public prosecutions in Scotland, with the view of amending that system if necessary and of extending to other parts of the United Kingdom the institution of public prosecutors."171 $\mathrm{He}$ thereupon delivered himself of an essay on public prosecutions in Scotland, including the inquisitorial method and a history of the Lord Advocates. Mr. George Denman concurred in the idea that a thorough investigation of the Scotch system should be conducted before England embarked on any program of public prosecutions. ${ }^{172}$ But the Lord Advocate of Scotland, Sir George Young, successfully opposed any such inquiry: ${ }^{173}$ the status quo thus again prevailed over the threat of change.

The Select Committee acted with dispatch and reported on May 30, twenty-six days after the referral had been made to them. But the reason for the speed was made apparent by the absence of content in the report. The 1870 Select Committee would add nothing to what its predecessor had accomplished. The only result was an amended bill.

The amendments, however, were substantial, and all looked in the direction of the earlier drafts. The pressures for economy gave way, and the scope of activity of the public prosecutor authorized by the amended bill was considerably expanded. $\mathrm{He}$ was to undertake the prosecution in all cases of indictable offenses for which the accused was committed, bailed, or detained; he might intervene in a prosecution for an indictable offense, even prior to that stage if so authorized by a justice or the Attorney General; on instruction from a justice or the Attorney General, he could seek an indictment; he might file an information against any persons suspected of crime, provided that counsel was informed of such action or he undertook to do so on instructions from counsel or the Attorney General; and he was to undertake prosecution in any case in which a true bill was returned, even if the defendant were not committed, bailed, or detained, if he were instructed to do so by a judge of the court in which the indictment was brought. Thus, the measure of costs was eliminated as a criterion for public prosecution replacing private action.

\footnotetext{
171201 HANSARd 465 (1870).

${ }^{172} I d$. at 472 . Denman was the son of the former Lord Chief Justice and was soon himself to don the judicial robes for many years of service.

${ }^{173}$ Id. at 474-77.
} 
If the area of action for the public prosecutor was expanded, the supervision under which he was to work was made more stringent. He was prohibited from withdrawing a prosecution, except by permission of the Attorney General, the court, or counsel. And counsel were required to "advise and direct the public prosecutors on all matters."174 Similarly, counsel were to act more closely under the supervision of the Attorney General, but cases were to be referred for opinion and directions to that official only through the Solicitor of the Treasury. The Attorney General was to instruct public prosecutors and counsel as to the institution and conduct of prosecutions as well as to the withdrawal therefrom. On the trial of cases, the Attorney General was authorized to act as counsel himself or conduct them through barristers whom he was to name. In this respect, the opportunities for patronage by the Government was somewhat extended. In other matters, however, it was reduced. Public prosecutors were to be appointed from among those nominated by specified local judicial authorities, except that temporary appointments could be made by the Secretary of State without such advice. And the number of counsel was limited to three, to be appointed by the Attorney General for five year terms, subject to renewal, but also subject to removal at the pleasure of the Attorney General. Though these offices were to be political in this regard, some safeguards against partisanship were also inserted. Public prosecutors were forbidden to partake in elections, except to exercise their franchise. And counsel were to be ineligible to be elected to Parliament or to serve or vote therein.

Private prosecutions were further inhibited by providing that private prosecutors were not to receive costs, except on special order of the court, in any case in which the public prosecutor had withdrawn from the prosecution or had refused to intervene in a prosecution where he was authorized to do so. On the other hand, care was taken to see that the jurisdictions of the Treasury Solicitor and of the Solicitor to the Post Office were unimpaired, and additional provision was made that any prosecutions which were in a category then being maintained by other government officials should continue to be so maintained until such time as the office in question was vacated by the death or resignation of the incumbent. Apparently, the original bill had not gone far enough in the protection of the bureaucracy.

The bill as amended was not yet one which the Government was prepared to see through the House. The bill was withdrawn on July

${ }^{174} \S 7$. 
8 , of that year, ${ }^{175}$ at the suggestion of the Home Secretary. ${ }^{178}$ The Government's line remained steady: the subject "hadn't yet received the consideration it deserved."177 And so, still another session of the House passed with no advance toward the goal of passage of a public prosecution bill.

\section{VI}

The I87I Bill

At the next session of Parliament, the very eminent Russell Gurney ${ }^{178}$ took over sponsorship of the bill, along with Messrs. Eykyn, Vernon Harcourt, and Rathbone. The bill which he presented for a first reading on February 15, 187 I, was a slightly amended version of the bill which had failed in the previous session. ${ }^{179}$ Hope had not dimmed among the supporters of the program. ${ }^{180}$

In one respect, the bill turned back to the original Phillimore proposals. It provided that the public prosecutor should not prosecute for defamation or assault or for default in maintaining any highway or bridge, except when he was instructed to do so by the Attorney General or, in the case of assault, by direction from the justice who ordered the accused bailed, detained, or committed. In other respects, the bill expanded the authority of the proposed public prosecutor. He was to be authorized to undertake prosecutions at the stage of the hearing on the presentation of an information, even without instruction to do so from higher authority. The most important change provided that $:^{181}$

Nothing in this Act shall be construed to exempt any clerk of assize, clerk of the peace, clerk of indictments, or other officers from any duty now belonging to his office, in respect of the preparation of indictments, or to exempt any constable or officer of police from the liability to perform any duty which he may now be liable to perform in respect of prosecutions.

The first reading was a mere formality. ${ }^{182}$ But the second reading was not moved until April 26, $187 \mathrm{I}$, and called forth a full-scale debate,

\footnotetext{
${ }^{175} 202$ HaNSARd I 710 (1870). ${ }^{378}$ See 203 id. at 408 (1870).

${ }^{177}$ Ibid. See the Times, July 19, 1870, p. 6, col. 3 .

${ }^{178}$ Gurney had been Recorder of London since 1857 and a Privy Councillor since 1865 .

${ }_{170}$ The Times vigorously applauded and supported the Gurney Bill. April 27, 1871, p. 9, cols. 2, 3 and 4. For descriptions of and comments on the bill, see 6 L.J. 278 (1871); 50 L.T. 374 (1871); is SoL. J. 398 (1871).

${ }^{180}$ See 15 SOL. J. 706 (1871).

$183 \S 28$.

182204 HANSARd $280(1871)$.
} 
the purport of which was to reveal that the situation which called for remedial legislation in the 1850 's continued unabated some two decades later. ${ }^{183}$

Russell Gurney opened the debate by apologizing "for introducing a measure which . . . ought to be in the hands of the Government, but had already been too long delayed." He then recited the history of the legislation, with special emphasis on the Report of the I855 Committee ${ }^{185}$ and the Select Committee Report of fifteen years later. ${ }^{186}$ His reasons for urging passage of the legislation were only too familiar to those who had followed its history. ${ }^{187}$ The Recorder of London, certainly as familiar with the processes of criminal law as anyone in England, painted a grim picture: ${ }^{188}$

Anyone who frequented our police courts would see upon whom the real duty of conducting a prosecution too often fell. He would see there a number of persons, sometimes attornies, much oftener persons practising in the names of attornies, who through personal touting, or through the intercession of policemen, got the prosecutors into their hands; and what did he see when the case was brought into Court? He saw a brief put into the hands of counsel at the last moment-the case negligently prepared-the counsel gaining his only valuable instructions from the policeman who was a witness in the case. ... The sight was not a pleasant one to one who felt for the character or honour of the Bar, and the effect on the police was bad, as they became not only witnesses but partizans.... [T] he evils which he described were not confined to the metropolis. ...

Gurney went on to point out that those towns which had adopted systems of public prosecutions were very well satisfied with the results

${ }^{183}$ These included a problem which has never been solved: the police interest in securing a conviction rather than a conviction only of the guilty. Time and again the papers could report: "They believed they had got the right man, and, so believing, they could recognize no evidence that did not fall in with their preconceived views." $5 \mathrm{I}$ L.T. 229 (1871). Cf. Borchard, Convicting the INNOCENT (1932); EdDowes, The Man on Your Conscience (1955); Frank \& Frank, Not Guilty (1957).

${ }_{184} 205$ HANSARD I 744 (1871); see 15 SOL. J. 476 (1871).

${ }^{185}$ See pp. $\mathrm{xx}$ - $\mathrm{xx}$ supra.

${ }^{187}$ Some circumstances had changed since 1855. A large new factor was the abundance of commercial frauds, involving comparatively small amounts so far as each of the defrauded individuals was concerned, but huge sums with regard to the defrauding parties. As an example, the Times made inuch of the Overend and Gurney stock frauds as a reason, among others, for the creation of public prosecutors. See, e.g. Times, July 7, 1869, p. 9, col. 5. It would appear, too, that conmercial frauds had caused the shift by the Law Journal from opposition to public prosecutors to support thereof. See 6 LAw J. 239-40 (1871).

${ }^{188} 205$ HANSARD $1746-47$ ( $187 \mathrm{I}$ ). 
obtained. And certainly, he alleged, only public prosecutors would undertake the prosecutions called for by the violations of the election laws. He then outlined the details of the bill and disposed of the objections to it. The patronage problem, he thought, had been taken care of by providing for appointments by the Government from a list provided by local magistrates. There was certainly no reason why counsel should not continue to be briefed in criminal cases as before. ${ }^{180}$ And while there would be some additional cost involved, the candle was worth the price.

Mr. West offered the major address in opposition. He asserted that "the practical men" on the Select Committee "were opposed to the appointment of public prosecutors." ${ }^{190}$ He offered the usual objections: expense, patronage, ${ }^{191}$ and injury to the purse and position of the clerks. "In his opinion, the most suitable public prosecutor, if any were appointed at all, would be the Petty Session clerks."102 The "present appointment of public prosecutors in Mint cases was doubtless dictated by political or personal interest, and the result was that the prosecutions directed by the Treasury were the worst conducted."193 And in Manchester, Liverpool, and Leeds, the briefs were "souped" out.

Sir John Parkington and Rathbone spoke for the bill and contested West's conclusions on expense and patronage. ${ }^{104}$ One point made by Rathbone can be fully appreciated only by Englishmen: "The reason:

${ }^{189}$ See acclaim for the handling of cases by young barristers by the Recorder of Warwick, a frequent correspondent to the Times on the subject of public prosecutions. Times, Feb. 26, 1871, p. II, col. 6. For an earlier letter, see id., March 12, 1868, p. 12 , col. $i$.

100205 HANSARD I 749 (I871).

$19 x$ "I may remark, en passent, that the assignment of jobbery comes rather ungracefully from a gentleman who either is or has been Recorder of Manchester, Judge of the Court of Record of Manchester, Recorder of Scarborough, Attorney General for the Duchy of Lancaster, Junior Counsel to the Admiralty, Counsel to the Post-Office, and Counsel to the Mint, on his circuit, and a Revising Barrister. But, as a matter of fact, there is far less chance that the prosecutions will fall into incompetent hands (and that is the real point) where the patronage rests with the leader of the Bar than if the patronage be left, as in many cases it now practically is, in the gift of some county magistrate who requests that a brief may be given 'to my son, a rising young man at the Bar, or my nephew, who aspires to forensic distinction.' " Letter to the Times, April 29, 1871 , p. II, col. 1 .

202205 HANSARD I 751 ( 1871 ).

193 I bid.

194 Patronage in the hands of the Attorney General aroused the opposition of at least some of the legal profession. See 6 L.J. $314(1871)$. Others found want of satisfaction in substituting the monopoly of the Government for that of the clerks, See id. at 297-99; see also id. at $346-48$; 50 L.T. 374 (1871); 5 id. at 35 (1871). 
why the Committee ... had not taken any evidence was because very exhaustive evidence had been taken by a Committee as recently as 1855 or ${ }_{1856 . " 105}$ So far as patronage was concerned: "The patronage devolving upon the Attorney General would be very trifling consisting only of his three assistant counsel, because the public prosecutors would be recommended by the magistrates."108

R. M. Straight, who had testified before the Select Committee some fifteen years previously on behalf of the clerks of whom he was one, reiterated his position. He favored public prosecutions, "by enlarging the authority of magistrates' clerks," who "were at present discharging the duties of public prosecutors."'187

Spokesmen for the Government announced their agreement with the principle of the bill, if not the details. Both the Attorney General, Collier, and the Home Secretary, Bruce, agreed that the bill ought to be in the hands of the Government. But this was just lip service. Other voices were raised on behalf of the bill as well as against it. Some of the latter suggested that the need for public prosecutors was restricted to London. The bill received its second reading, ${ }^{108}$ but died at this stage. And on June 7, I87I, near the close of the session, Russell Gurney announced "that there was no reasonable prospect of his being able to carry the Bill during this Session, but that he would take the earliest opportunity, if the Government did not take up the subject, of introducing a similar Bill next Session. ${ }^{199}$ Meanwhile, Lord Chief Justice Cockburn was apparently using his office to condemn the absence of public prosecutors. ${ }^{200}$

\section{VII}

\section{The I872 BiLL}

When Parliament next convened, however, Russell Gurney was in Washington, D. C., on behalf of Her Majesty's Government, engaged

\footnotetext{
${ }^{205} 205$ HANSARD 1754 (1871). (Emphasis added.)

${ }^{200} I d$. at 1755 .

${ }^{207} I d$. at $1756-58$.

${ }^{208}$ On a division of the House, 129 favored the bill, 89 opposed it. Times, April 27, 187 1 , p. 6, col. 5 .

${ }_{200} 205$ HANSARD 1767 (187x). The Solicitors Journal, ever hopeful, announced: "Surely, we may fairly anticipate that a third session will not be allowed to pass away without enactment." 15 SoL. J. 706 (1871). Others were less sanguine: "Doctrinaire and theoretical measures come in plenty; but a plain practical one, like a prosecutor's bill, is, of course, too insignificant for Parliament." 5x L.T. 263 (187I); cf. 52 id. at $125(1871)$.

${ }^{200}$ See, e.g., 6 L.J. 329 (1871); 7 id. at 227 (1872).
} 
in negotiation of claims between the United States and Great Britain arising out of the American Civil War. Leadership of the proponents of the bill fell to Spencer Walpole. ${ }^{201}$

The new bill ${ }^{202}$ contained some variations from its immediate predecessor. It offered to take advantage of the experience of those who had been acting as public prosecutors by authorizing the appointment of any one acting in that capacity for the three years previous to the enactment of the legislation, providing that he was a solicitor or attorney. In order to discourage the maintenance of a prosecution by a private prosecutor after the withdrawal from the action of the public prosecutor, it provided for the discharge of the recognizance of the prosecuting witness and of the subpoenas of the other witnesses when the public prosecutor retired from the case. In addition to these minor revisions, a major change was made, also for the purpose of encouraging public prosecutions at the expense of private prosecutions. Property owners or their representatives were to be entitled to the benefit of the judgments secured by public prosecutors in criminal proceedings involving property crimes. But a condition was imposed: such benefit would not be available to any property owner or his representative who, in the opinion of the court in which the case was tried, failed "in giving all reasonable information and assistance in relation to the prosecution"203 to the public prosecutor. And the court was empowered to issue a certificate of default, which would make the judgment of conviction unavailable to the property owner for purposes of res adjudicata.

The bill came up for its second reading on February $16,1872 .{ }^{204}$ Its first reading had been a mere formality. ${ }^{205}$ Walpole reiterated the defects in the existent prosecutorial system for the benefit of the House. "... [I]t may be said," he alleged, "that impunity for crime was almost the rule, and the punishment the exception."208 $\mathrm{He}$ attacked the police as prosecutors, rejected the argument that the bill would put unreason-

${ }^{901}$ See 52 L.T. 270 ( 1872 ). Walpole had thrice been Home Secretary under Derby and had been an active and leading member of Parliament since 1846 .

${ }^{203}$ For a summary of the bill, see 7 L.J. $210(1872)$. The Times saw new fuel added to the fire by the experience in the Tichborne case, in which each of the Law Officers had been engaged by the parties, so that none was available to prosecute. Times, March 8, 1872, p. 9, col. 3 .

.${ }^{203} \& 30$.

204209 HANSARD $587(1872)$. Some of the difficulties of privately sponsored bills, as distinguished from those backed by the Government, are detailed in the Times, June 2.1, 1872 , p. 9, col. 3 .

205209 HaNSARD $140(1872)$.

sos $1 d$, at 588. 
able patronage in the hands of the Attorney General, asserted that counsel on the circuits would continue to be briefed under the bill as they were under the system then in effect, denied that the need for reform existed only in the cities, and refused to venture an opinion as to the amount of increased expense which would result from the enactment of the bill. He concluded that a "public prosecutor was required for England as much as for Scotland and Ireland."20z Walpole offered to postpone further consideration of the bill until after the return of Russell Gurney, if the bill were to receive its second reading.

Although West once again rose in opposition, he indicated he would consent to the second reading, so that the bill would be in the same posture as it had achieved in the previous session by the time that Gurney returned. He indicated that he would consent to public prosecutions if the public prosecutor were to take over a prosecution from its very inception, as in France and Scotland. But he was opposed to the immediately proposed measure for the reasons which he had previously stated. ${ }^{208}$ Straight then rose to announce his disapproval, not on the usual ground that the job should be turned over to the magistrates' clerks, but because there really was no great need for reform. "He was much surprised at [Walpole's] observation that the present state of things led to a failure of justice. He believed that that was an impression founded on exaggerated statements in articles and reports in the newspapers."209 And still another familiar voice in opposition was heard: Mr. Leeman repeated his proposal that the bill be limited to the Central Criminal Court; "if the people of London wished it, let them not force it upon the provincial counties and boroughs, which, to use a Yorkshire phrase, had no more use for it than a cow had for a watch pocket."210

At this point, the bill seems to have been adopted by the Government. The Home Secretary rose to speak in defense of the bill: ${ }^{211}$

[He] would remind the House that nobody had ever supposed that the Bill would pass through the House, without the strong opposition of many of the legal Members; but, on the other hand, no one could deny that in the opinion of the highest judicial authorities of the land, the present system was faulty, and necessity for a public prosecutor was a real serious one. The Bill might not be perfect, but he believed it contained the elements of a great and useful reform.

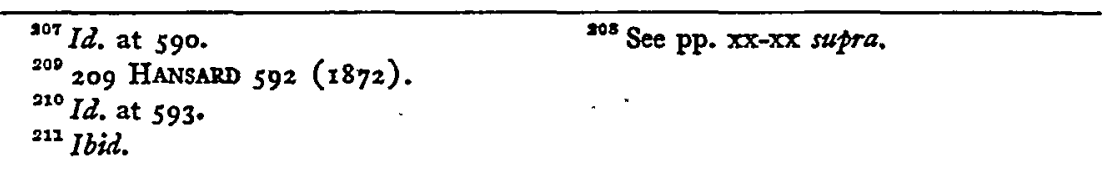


After further debate, Eykyn speaking for the legislation and Wheelhouse in opposition, the bill received its second reading and was committed "for the following Friday."

By the time the bill came before the House for its final reading, the Government had noticed a large number of amendments. Indeed, with the amendments, the bill was hardly recognizable as the one offered by Gurney and Spencer Walpole. ${ }^{212}$ If this was its virtue, it was also, as was soon to be demonstrated, its vice.

As amended, the bill called for the public prosecutor, acting pursuant to regulations which were to be promulgated under the Act by a Secretary of State, to conduct the prosecutions of all persons committed, bailed, or detained for trial for any of the offenses listed in the appended schedule. The schedule, which was subject to amendment by regulation, included all felonies, attempts or conspiracies to commit felonies, riot, neglect or breach of duty by a peace officer, wilful and indecent exposure, wilful and corrupt perjury or subornation of perjury, and certain specified indictable misdemeanors. The list would put into the charge of public prosecutors, in addition to all major crimes, those acts which were directed primarily at the undermining of the existent system of prosecutions as detailed in the 1855 hearings.

Though the bar was still dissatisfied, ${ }^{213}$ the justices' clerks had won a partial victory. Outside of London, public prosecutors were to be appointed only in those boroughs and counties which passed an enabling law. But strong incentive to pass such acts was offered. In those boroughs and counties which chose to institute this system of public prosecutions, the public prosecutors were to be paid salaries fixed by the Treasury out of Treasury funds. The costs of prosecutions were

\footnotetext{
${ }^{212}$ For a summary of the amendments, see 7 L.J. 487 (1872); 52 L.T. 138,276 (1872).

213 "Sir Eardley Wilmot [see note 189 supra] has written a very sensible letter on the subject of public prosecutors. We have stoutly opposed the various schemes to throw all the criminal business of the country into the hands of paid officials, both on public and professional grounds. We hold that the business of the public prosecutor should be limited to those cases in which private persons are not willing to undertake important prosecutions. The public prosecutor should relieve the police of responsibility that ought not to be cast upon them-that of deciding upon prosecution. We should not object to the appointment of a barrister in each county or district to direct attorneys charged with prosecutions undertaken by the public authorities. But we protest against any attempt to inake the criminal business of the country an official monopoly." 7 L.J. $144(1872)$. A conflict between the two branches of the legal profession as to which was to fill the role of public prosecutor was deplored by the Solicitors Journal. "We see no reason, therefore, for any class opposition to the bill; and on public grounds we decidedly approve of it." 16 Sol. J. $319(1872)$.
} 
to be borne by the local government where the borough or county had opted for private prosecutions, but by the Treasury in the event public prosecutions were instituted. Appointments of prosecutors were to be made by the appropriate Secretary of State, but only from lists submitted by the local authorities. A nominee of the local authority was required to be ${ }^{214}$

a fit person, being an attorney-at-law who either is a clerk to special and petty sessions or a clerk to justices in such borough or county, and is paid by salary, or who not being such a clerk has practised in such borough or county for not less than three years immediately previous to his appointment.

The nominee who was appointed would hold office at the pleasure of the Secretary of State, and was disqualified from carrying on any practice in other criminal matters.

In the district for the Central Criminal Court, the appointment of public prosecutors was made mandatory, without the need for permission or approval of the local authorities. And the prosecutor so to be appointed was to be chosen solely at the discretion of the Secretary of State.

Where the public prosecutor was not also the clerk, clerks were commanded to forward, on demand, all documents and depositions relevant to the criminal action in which the defendant had been committed, bailed, or detained. The coroner was also to assist the public prosecutor in this manner. The duty of seeing that these documents were placed in the hands of the court where the case was to be tried was thus passed on to the public prosecutor.

Such prosecutions as were undertaken by the public prosecutor were to be in his sole charge, subject to such limitations as the regulations might make. In those cases "no person shall be bound over . . . to prefer a bill of indictment."215

An interested party might, on such terms as were to be prescribed by the regulations, be "associated" with the public prosecutor in the conduct of the prosecution. Provision was made, however, upon a showing by an individual that the public prosecutor was not properly fulfilling the assignment made to him by the law, for the High Court or a judge thereof to order the private person substituted for the public prosecutor to carry on the prosecution. With this exception, and with the exception of the crimes not contained within the schedule, all cases were to be conducted by the public prosecutor, who was not to be per-
${ }^{214} \S 6$.
${ }^{215} \S 5$. 
mitted to withdraw from a prosecution, except with the consent of the court in which the case was to be tried.

Other important revisions of the bill called for the payment of witnesses' expenses, whether the witnesses were those called by the prosecution or those called for the defense, provided that clerks were to be paid by salary rather than by fee, and made patent the obligation of the police to render such assistance to the public prosecutor within the borough or county as should be called for by that official.

As soon as the bill and its amendments came before the House sitting as a Committee of the Whole ${ }^{218}$ - the first time a bill for the appointment of public prosecutors arrived at this stage of enactmentMr. Sclater-Booth ${ }^{217}$ was on his feet protesting the propriety of the amendments. He was at a loss, he said, to know who was managing the bill. It had been brought in as a private members' bill, but the amendments were noticed by the Government. It was his opinion that the Government should accept responsibility for the bill, especially in the light of the amendments which I) put the entire cost of prosecutions on the Exchequer if the local authorities so exercised their options, and 2) proposed to place clerks of the peace on a salary basis in lieu of the fee system which had theretofore prevailed.

Mr. West once again rose in opposition on the ground that the information as to costs of prosecutions which was the subject of a departmental inquiry ${ }^{218}$ had not been available to the House. And then the big guns of the House wheeled into action. Spencer Walpole asserted that the amendments proposed were in direct response to the objections which had been raised on the second reading. He thought the compulsory appointment of a public prosecutor for the Metropolitan area was a wise change. And while he still felt that the necessity for public prosecutors existed in the remainder of the country as well, he approved giving discretion to the local populace in each borough or county to determine whether they desired to adopt the practice. Edward PlydellBouverie $^{219}$ objected that the amendments made such fundamental changes in the bill that it was no longer the same bill which had

210211 HANSARD 1950 ( 1872 ).

${ }^{217}$ Sclater-Booth, later to be elevated to the peerage as Lord Bosing, was then a magistrate in his home county. He was not yet in possession of the prominent place he was to hold on the Treasury bench from 1874 to 1880 .

2182 I I HANSARD 1507 ( $\left.187_{2}\right)$.

${ }^{210}$ Plydell-Bouverie was a protégé of Palmerston and had been an M.P. since 1843 . He had twice served as Under-Secretary for the Home Department as well as Vice-President of the Board of Trade and President of the Poor Law Board. 
received the second reading in the House some months before. VernonHarcourt defended the Government's failure to sponsor the legislation for want of time. He saw no basic changes in the Government's proposed amendments from the principle which had been previously approved. The principle was that public prosecutors should be appointed, whether the local authorities should be compelled to adopt the system or were to reject it was a mere matter of detail. But Gathorne-Hardy ${ }^{220}$ agreed with Bouverie that it was a new bill with the amendments. Ironically, it had been Gathorne-Hardy, later Earl Cranbrook, a good friend of Spencer Walpole's, who had been elected to represent Leominster in 1856, the constituency which had earlier returned Phillimore as its representative. After this attack, the incumbent Home Secretary rose, not in defense of the amendments, but in defense of the Government's procedure. He agreed that the proper course would have been for the Government to bring in a new bill, but there was no time for that. It had been ${ }^{221}$.

impossible for the Government to undertake the conduct of this Bill without abandoning other measures to which they were pledged, and the Government were entirely in the hands of the House with reference to this question. If the House expressed a desire to proceed with the Bill, the Government would be most happy to facilitate its passage by every means in their power, if on the other hand, for the reasons stated ... the House thought the Bill ought not to be proceeded with, the Government would be content to yield to that opinion.

Bruce had made it clear that the whips were off.

Mr. Henley "never remembered a case in which the House and the country had been less fairly treated."222 And so far as the amendments were concerned, he supplied the rallying cry of the opposition by damning the offer to undertake the costs of prosecution where public prosecutors were appointed as a "bribe." Mr. Magniac agreed. $\mathrm{He}$ had a groundless fear that the amended bill would permit clerks who were appointed as public' prosecutors to "carry on prosecutions in defiance of the magistrates. That was certainly most objectionable."223 If nothing else, this made it apparent that the satisfaction of the de-

${ }^{220}$ Hardy, the leader of the Conservative forces in Commons when Disraeli was absent, had been Home Secretary and was again to achieve Cabinet rank as Secretary of State for War and later Secretary of State for India. In 1865 , he had defeated Gladstone at Oxford.

222 2II HANSARD 1958 (1872).

s32 Ibid.

${ }^{33}$ Id at 1959. 
mands of justices' clerks was not equal to satisfying the desires of the justices themselves. . Bruce explained "that under the Bill, clerks of the justices, if appointed public prosecutors, would only have the power to prosecute where offenders had already been committed for trial."224

Assheton-Cross asked for recommital, so that the House might have time to study the amendments. George Ward Hunt ${ }^{225}$ asked for recommittal because of the "unlimited" costs which the public prosecutors might impose on the Exchequer. He joined in the cry of "Bribel" And so did Mr. Leeman, who asked in addition that recommittal take place so that the views of the justices at quarter sessions might be secured.

'Mr. Straight's record of opposition was maintained, though he had to shift ground. He heartily approved of giving the posts of public prosecutors to the clerks. ${ }^{226}$ Indeed, he would extend their role to include control of prosecutions prior to the time of committal of the defendant for trial. But he would adjourn consideration of the amendments, and if the bill failed to carry, he trusted that the Government would take it up at the next session. Mr. Winterbotham, the UnderSecretary for the Home Department, unlike his chief, defended the amendments as well as the Government procedure. The delay in bringing in the bill, he explained, was due to Russell Gurney's absence in America. But the Recorder of London had approved the amendments. Winterbotham then responded to West's request for information on costs of prosecutions which had been secured by the departmental inquiry and took exception to the accusations of bribery.

Quite clearly, the bill and its amendments could not carry that session of the House. Eykyn expressed the hope that the Government would pledge itself to bring in a new bill at the next session. He stated, also, his regrets that the Law Officers had not seen fit to inform the House of their views on the subject. ${ }^{227} \mathrm{Mr}$. Wheelhouse, with his usual perspicacity, could not see that the delay could cause any harm, since the new system would be as bad as the old one.

The wake was somewhat lightened by the Irish members present. Mr. M'Mahon asked for a Select Committee to report on the working

\footnotetext{
${ }^{224}$ Ibid.

- ${ }^{225}$ Hunt was then a Privy Councillor and a Chairman of a quarter sessions. He had been Chancellor of the Exchequer and was to be first Lord of the Admiralty. ${ }^{228}$ This change apparently brought some clerks to support the bill. See, e.g., 7 L.J. 227 (1872); 52 L.T. 448 ( 1872 ).

$=27$ The Law Officers apparently were not present during the debate. Times, June $2 \mathrm{r}, 1872$, p. 9, col. 4. .
} 
of the Scotch, Irish, and French systems. As for Ireland, he knew that $^{228}$

the system of public prosecutions had led in a great measure to the failure of justice, owing to the want of local knowledge, and to the carelessness with which the prosecutions were got up and conducted. In that opinion, Sir Joseph Napier and Chief Justice Whiteside concurred, and the former in his evidence spoke of the "slovenly and slobbering manner" in which cases were prosecuted, and the result was an unusual number of acquittals. So much was this the case, that prisoners on leaving the dock free were heard to say- "God bless Her Majesty; she employs counsel nobody else would think of having."

This, of course, brought forth appropriate responses from a $\mathrm{Mr}$. Maguire and Mr. Dowse, the Attorney General for Ireland.

Finally, Russell Gurney, who had returned from his mission to the United States in time to witness the demise of his bill, delivered the requiem::220

In reply to the objection that the question was being hurried on, he would say only that it had been before the House and the country for nearly twenty years, and that on the Select Committee which sat to inquire were the Lord Advocate, the Attorney General for Ireland and the English Attorney General, all of whom were warmly in favour of the appointment of a public prosecutor.

But he recognized that the amendments were so basic that the bill should be recommitted. It was recommitted on June 19,1872 , and one month later it was withdrawn. ${ }^{230}$

When, at the next session, Mr. Eykyn asked the Home Secretary "if it is intended to bring forward the Public Prosecutors Bill this Session," ${ }^{231}$ Mr. Bruce responded ${ }^{232}$

that he had, on the part of the Government, undertaken last year to introduce a Bill, and he had not abandoned that intention. In consequence, however, of hearing that the Judicature Commission were about to take the question into consideration, he postponed the introduction of the Bill until he should have the benefit of the recommendations of the Commissioners, and the Bill, which he hoped soon to introduce had been framed after consideration of those opinions, and in general conformity with them.

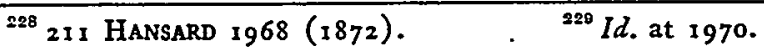

230212 id. at $1413(1872)$.

${ }^{882} 215$ id. at 104 (1873). See also 54 L.T. 332 (1873).

232 215 HANSARD $105(1873)$. This announcement again falsely raised the hopes of the Solicitors Journal. 17 SoL. J. 325 (1873); see $3 d$. at 424 .
} 
In spite of this statement to the House, Bruce did introduce a bill later in the session without waiting for the report from the Judicature Commission. In addition to Bruce, the sponsors for the bill were the Attorney General, Sir John Duke Coleridge, who was to succeed Cockburn as Lord Chief Justice of the Queen's Bench, after first serving as Chief Justice of Common Pleas, and Mr. Winterbotham, the UnderSecretary of the Home Department. Gladstone's "heaven-born Home Secretary" brought in the bill on May $22,18733^{233}$ in a form which was hardly calculated to succeed in placating the opposition to public prosecutors. Although it retained some of the provisions of its predecessors, the bill submitted to the House contained many new features. It provided that a Secretary of State was to appoint attorneys from time to time to serve at his pleasure "for the purpose of conducting the prosecution of persons committed ... for trial for any of the offenses mentioned in the first schedule"-which remained the same as in the predecessor bill-"and of instituting and conducting such other criminal proceedings as may be directed by the Secretary of State, or may be prescribed by regulations ...., and the attornies so appointed are ... referred to as public prosecutors."234 The Secretary of State was to fix the number of public prosecutors and designate the districts in which they were to serve; he was to assign their duties, supervise their activities, and, with the concurrence of the Treasury, fix their salaries. Power under the new bill was thus centralized not only in the Government, but more particularly in the Home Secretary.

A completely new provision called for the appointment of a solicitor for the Home Department, incorporating by reference the terms of the statute which had created the office of solicitor to the Treasury. ${ }^{235}$ Boroughs and counties were to be exempted from being assessed for any of the costs of prosecutions which would be conducted under the provisions of the bill.236 And provision was made for permitting clerks to justices in boroughs to act as public prosecutors, presumably to allow the continuance of the systems of public prosecutions then existent in some of the major cities of the country. In all other respects, the bill reiterated the provisions to be found in its predecessor.

Some doubt may be expressed as to the expectation of the Government that they would succeed with such a measure. They had removed

\footnotetext{
${ }^{280} 216$ HANSARD $269(1873)$. For descriptions of the bill, see 53 L.T. 276 (1873); 17 SoL. J. 587 ( 1873$)$.

${ }_{284} \S 3$.

${ }^{285} 9$ Geo. 4, c. 25 (1828).

${ }^{280} \S 5$.
} 
the concessions to the justices' clerks outside the boroughs, they had eliminated the power of the local authorities to nominate the attorneys who were to serve as public prosecutors, and, in so far as local option was no longer permitted, the central government would determine in which cases the costs were to be borne by the local authorities and in which the central government would foot the bill, a discretion which could be exercised in a discriminatory manner. It is not surprising that the bill received no discussion in the House and was withdrawn six weeks after it was introduced. ${ }^{237}$ Its importance lay in the precedent which it set. The ultimate enactment of a public prosecutors bill was to adopt the proposal to vest power and discretion in the Government.

\section{VIII}

\section{The Judicature Commission Report}

Mr. Bruce had something of the modern sociologist about him, however, and he circulated the 1872 and 1873 bills among the judges, recorders, magistrates, and clerks of the realm, seeking an impression of their opinion. Like more recent but similar searches, the response was good but the results were inconclusive. The general tenor of the replies, however, especially from the justices of the peace and their clerks, was in favor of the maintenance of the existent system, a viewpoint which had been forcibly revealed by their representatives in the House of Commons. But even some high court judges indicated a similar bias. Baron Bramwell was "satisfied that there should be no public prosecutors other than or in addition to those who in many cases perform that sort of duty ... the police and magistrate clerks." But he thought "the functions of public prosecutor ought to be exercised or exercisable before commitment." The police did their duty "very well," but he thought they should be subject to supervision by "a public prosecutor with knowledge of the law, or a person to whom they might apply for advice and assistance." Mr. Justice Mellor, too, thought that the scheme was defective in not providing for "an earlier and more direct system of communication between the police and the public prosecutor," for "the utility of the public prosecutor will much depend on their giving advice and direction to the police in their investigation of the circumstances surrounding the commission of a crime in the earlier

${ }^{237} 216$ HANSARD 1851 (1873). On being asked whether the Government would again bring in a bill at the next session, Bruce replied in the usual evasive fashion which Home Secretaries had used to answer this question every time it was put. Times, Aug. 6, 1873 , P. 6, col. 3 ; 53 L.T. 276 (1873). 
stages before a charge is made before a magistrate." He did not believe that public prosecutors would be an improvement over the magistrates' clerks. But if any such system were to be adopted, he thought it ought to be effected in the country areas as well as the Metropolis, and that all the prosecutors thus appointed should be responsible directly to the Home Secretary or the Attorney General. Baron Clearly thought that there certainly was no need for public prosecutors in felony cases and, therefore, that they should be appointed to act only on request from the committing magistrate. Nor did he believe that police prosecutions were poorly managed. "The fault has been in the police taking to the case with too much anxiety to convict, and the consequence has been that the accused has not always been fairly dealt with. ... But I do not see how the public prosecutor could deal with this mischief or dispense with the police in proving and influencing the evidence."238

With the evidence contained in the replies to the Home Secretary's letters before them, the Judicature Commission appointed a committee for resolving the issue whether a system of public prosecutions was called for, and, if so, what the nature of that system should be. The Commission itself, presided over by Lord Cairns, was a distinguished one: a list of its members would have included a large portion of the "Who's Who" among English jurists. The committee which was appointed to deal with the specific question was equally learned, and the majority report was prepared by one of its most able members, Colin Blackburn, then Judge of the Queen's Bench. And the dissenting report was prepared by Lord Chief Justice Cockburn.

Before the Report was issued, however, the question was raised again in the 1874 session of Parliament by Sir John Eardley Wilmot, Recorder of Warwick, ${ }^{239}$ whether the new Government planned to bring in a bill for the creation of the office of public prosecutor. Sir Richard Assheton-Cross, the new Home Secretary, replied with exactly the same evasion as had his predecessors in office: "the hon. Baronet would be perfectly aware that it had been under the consideration of the Judicature Commission, and it would be some weeks before their report on it was received. When that Report was presented, it would obtain the

\footnotetext{
${ }^{238}$ Quotations from the letters of Baron Bramwell, Mr. Justice Lush, Baron Clearly, Mr. Nicholson, and Mr. Saunders are reported at ro L.J. 568 (1875). A report of the consideration given by some of the quarter sessions is in 17 SoL. J. 189 (1873); sce also 5o L.T. 453 (1871); 54 id. at 332 (1873).

${ }^{238}$ See notes $189,21.3$ supra.
} 
most careful consideration at the hands of the Government."240 There was no hint or suggestion of a commitment on the part of the administration to support the proposal which might come from the Judicature Commission. ${ }^{241}$

Indeed, the Commission itself never took a stand on the question, for it was doubtful of its authority to deal with it. But its committee felt no doubts. ${ }^{242}$ "The Committee is unanimous," Blackburn reported, "in thinking that it is advisable that a Public Prosecutor should be appointed. It is also unanimous in thinking that it is desirable that there should be a Chief Public Prosecutor in the Metropolis with a sufficient staff and subordinate Public Prosecutors in different districts."

Blackburn's analysis broke criminal prosecutions into three categories. In the first were "matters not really of a criminal nature," such as indictments for obstructing roads, which ought to be the sole consideration of the offended private parties. The second category involved those actions which he deemed to be in the nature of redress for private wrongs, such as prosecutions for common assaults, libels on private persons, and private nuisances. In these cases, the suggestion was that public prosecutors not intervene, except on instruction from higher authority, presumably the Attorney General or the chief public prosecutor. The last group included all the remainder of criminal offenses, felonies and misdemeanors, which ought to be made the direct concern of the public prosecutors.

According to Blackburn, criminal prosecutions proceeded in four stages. The first was the investigation of the commission of a crime and the apprehension of the accused for purposes of bringing him before the magistrate. While this work "was satisfactorily conducted by the police," there was an area for supervision and advice in particular cases by "a person of superior skill and intelligence."243 The second stage was the presentation of the evidence before the magistrate. This was "in general satisfactorily conducted by police, but there are exceptional cases in which the intervention of a Public Prosecutor would be of great use."244 Blackburn noted that the problem of collusive withdrawals of prosecutions continued to exist. The third step was that of "getting up

${ }^{210} 218$ HANSARD 917 (1874).

2A1 The young James Bryce, not yet a trusted advisor of Governments, had advocated a Ministry of Justice and a public prosecutor in The Organization of a Legal Department of Government, I3 FoRTN1GHTLY REV. (N.S.) 316 (1873).

$242[1874]$ XXIV Parliamentary Papers $307,319$.

248 Id. at 320 .

2at Id. at 321 . 
the brief," which was "in practice almost entirely neglected." brief delivered to the prosecuting counsel, in the great majority of cases, consisted merely of the copy of the depositions taken before the magistrate. It was here that the greatest service could be made by a public prosecutor. The last of the stages defined by Blackburn was the trial itself, which the committee thought to be "at present in general satisfactory, in so far as it can be, when the case is improperly got up."240 The committee, however, took exception to the police acting as prosecutors in cases in which they were also to testify as witnesses, for they were convinced that this created a bias which was hardly becoming to the role which a witness should play.

In the light of his analysis, Blackburn recommended that there should be a Chief Public Prosecutor, located with his staff in London, who was to be charged with the supervision of local prosecutors in each district. The areas of England and Wales outside of the Metropolis were to be divided into districts, with one or more resident prosecutors in each. The chief public prosecutor was to have the status of an Under Secretary of State, who would not change with the change of ministries, but who would be subject to removal at the will of the Home Secretary. The local prosecutors were to be appointed by the Chief Public Prosecutor and were to be removable from office by him.

While the local prosecutors would be responsible for the conduct of their office, they were free to call upon London for advice and assistance. And the prosecutors in the office of the Chief were to be assignable from time to time for duty in the provinces. All prosecutions falling into the third of Blackburn's categories would be conducted by the public prosecutors and, in addition, such other prosecutions as the chief public prosecutor, the Home Secretary, or the Attorney General directed them to take. All cases were to be reported by the police or the local magistrates to the chief public prosecutor, so that he might make a judgment as to whether they should be undertaken by the local public prosecutors. It was also to be the function of the locals to give advice to the police when requested to do so, in any case. And they were charged with rendering assistance to defendants whenever they were "too poor, or too ignorant" to protect their own interests "or in cases of suspected sanity [sic]."247 It was also suggested that the power to investigate the commission of crime be given to the chief public prosecutor.

\footnotetext{
${ }^{245} 1 b i d$.

240 lbid.

${ }^{247}$ Id. at 323 .
} 
No change in the method of trial was suggested. The local public prosecutors were to brief counsel of their own choosing. But the powers of the Attorney General were to remain unrestricted. And the Home Secretary was to have the obligation to issue governing regulations.

It was recognized that the proposals were tentative and that the new scheme should operate concurrently with the right of private prosecution. "Should a scheme for Public Prosecutors be framed and work so as to give satisfaction, it is probable that private prosecutions would cease to be instituted."248 Blackburn has been proved a true prophet.

Lord Cockburn would have none of the hesitation to impose a system of public prosecutions for all cases. Every crime was an offense against the community, and the state was, therefore, responsible for prosecution of the offender. He admitted that the existent system worked fairly well in simple cases, but he alleged that it broke down completely in difficult prosecutions. It was his idea, therefore, that a public prosecutor be authorized to act in every case. Aside from this difference with the majority, Cockburn made a defense against the problem of additional expense, a position consistent with his ideas, since he wore ermine, but not reconcilable with that first taken by him when, as Attorney General, he spoke in opposition to the Phillimore bill: ${ }^{249}$

The question should not be considered as one of pounds, shillings, and pence, but should be looked at solely with reference to the means by which this department of the administration of justice can be most effectively carried on. No economy can be more ill judged than that which would make the prosecution of offenders with a view to the suppression of crime a matter of pecuniary consideration. Our business . . . is to suggest the means by which the prosecution and conviction of offenders may be most effectively carried on and insured, leaving to the Government and the Legislature to determine whether our recommendation shall be carried out or not. Of one thing I am assured, that it would be better to leave things as they are than to substitute for the existing system anything which shall not be a comprehensive and thoroughly efficient institution in the place of it: ${ }^{250}$

If the committee report ${ }^{251}$ which was carried in the Judicature Commission's Fifth Report had no other effect, it did result in the Govern-

${ }^{248} I d$. at 320 .

"sis See p. xx supra.

${ }^{250}$ [1874] XXIV Parliamentary Papers 327-28.

${ }^{252}$ A summary of the Report is to be found at 18 SoL. J. 863 ( 1874 ) ; 57 L.T. 332 (1874). The Times came out strongly for the Cockburn recommendations. Sept. 4, x874, p. 7, col, 2 . 
ment's inclusion in the Queen's Speech to the 1875 session of Parliament a recommendation that it direct its attention "to legislation for the better security of my subjects from personal violence, and for more effectually providing for the trial of offences by establishing the office of a Public Prosecutor."252 But it would appear that if Her Majesty's message was heeded at all, no evidence was created of such attentiveness. The Government did not introduce a bill on the subject in that session of the legislature, in spite of its announced intention to do so. ${ }^{253}$ Questions were repeatedly put to the Home Secretary about the introduction of a bill in the 1876 and 1877 sessions, but to no avail. ${ }^{254}$ And in the I 877 session, notice was given to the House that in the absence of a bill for public prosecutors, a private member proposed to introduce a resolution that it was the opinion of the House that a Minister of Justice should be appointed. ${ }^{255}$ In the 1878 session, a private bill calling for public prosecutors was introduced by Wilmot, Walpole, Mr. Watkin Williams, and Sergeant Simon, but it was not even printed. ${ }^{250}$

\section{IX}

\section{The Prosecution of Offenses Bill}

Finally, in the I879 session, the Government brought in the bill which was to become the Prosecution of Offenses Act of $1879 .^{257}$ The bill carried the names of the Home Secretary, Sir Richard AsshetonCross, the Attorney General, Sir John Holker, Sir Stanley Hasting Giffard, ${ }^{258}$ and the Under Secretary of the Home Department, Sir Matthew Ridley. Except for the abortive effort of 1874 , this was the first bill proposing the use of public prosecutions which came before the House as a Government measure rather than a private member's bill. The difference was immediately noticeable. The bill received its first

\footnotetext{
${ }^{252} 222$ HANSARD 6 (1875). The Law Journal, which had straddled on this question, was once again on the side of public prosecutions, 9 L.J. 527-28 (1874).

${ }^{253}$ See 33 Economist 577 (1875); Times, May II, 1875, p. 6, col. 4. The retreat was sounded by Cross later in the session. Times, Aug. 6, 1875, p. 7, col. 2.

${ }^{256}$ See Times, Feb. 22, 1876, p. 6, col. 3 ; id., May 26, 1876, p. 6. col. 23 see also 62 L.T. 440 (1877); 20 Sol. J. $593(1876) ; 21$ id. at 483 (1877). The issue was raised outside Parliament as well. See, e.g., 12 L.J. 14 I (1877); 5 I WestMinster REV. 1, 18 (1877).

${ }^{258}$ See 21 SoL. J. $670(1877)$.

250 237 HANSARD $1139,1205,1286(1878)$. The Government also had a bill prepared which it did not introduce. Times, Aug. 9, 1878, p. 6, col. 2.

${ }^{957} 42$ \& 43 Vict. c. 22 ( 1879 ). A report of the bill may be found at 14 L.J. 347 (1879); 23 Sol. J. 324 (1879).

${ }^{258}$ Later the first Lord Halsbury, thrice Lord Chancellor.
} 
reading without debate on February $14,1879,{ }^{259}$ and its second reading, again without debate, less than a week later. ${ }^{260}$ Exactly one month after its first reading, it was moved for consideration in the Committee of the Whole House.

The new bill in no way reflected the report of the committee of the Judicature Commission. It authorized, but did not require, the appointment of a Solicitor for Public Prosecutions by a Secretary of State, and also allowed for the appointment of assistants by the Attorney General, if the Treasury acquiesced. All of these officials were to be either barristers or solicitors, with the Solicitor being required to have a minimum of ten years' practice in his profession and the assistants a minimum of seven years. In order to hold one of these posts, the incumbent was required to give up all private practice.

The Attorney General was also charged with issuing regulations which would govern the conduct of these new officials. But the regulations would be effective only after they had been approved by the Lord Chancellor and a Secretary of State, and after they had been laid "before each House of Parliament for not less than forty days upon which such House has sat. "261

The duties of the Solicitor were to act: ${ }^{262}$

Under the superintendence of the Attorney General, to institute, undertake, or carry on such criminal proceedings..., and to give such advice and assistance to chief officers of police, clerks to justices, and other persons, whether officers or not, concerned in any criminal proceeding respecting the conduct of that proceeding, as may be for the time prescribed by regulations under this Act, or may be directed in a special case by the Attorney General. The regulations under this Act shall provide for the Solicitor for Public Prosecutions taking action in cases which appear to be of importance or difficulty, or in which special circumstances, or the refusal or failure of a person to proceed with a prosecution, appear to render the action of such Director necessary to secure the due prosecution of an offender.

Provision was also made for the justices and coroners to forward to the Solicitor for Public Prosecutions, whenever directed to do so by the Solicitor or by the Attorney General, all relevant documents in the prosecution, including the depositions. Similarly, the clerks were commanded to forward copies of the information, depositions, and other relevant documents in all cases in which the prosecutor has withdrawn the prosecution or has failed to proceed with it. Sanctions were added

\footnotetext{
250 HANSARD 1108 ( 1879$)$.

$201 \S 8$.

${ }^{260} 1 d$. at 1507 .

$302 \S 2$.
} 
for the first time providing for the imposition of penalties on clerks or justices who failed to comply with these provisions.

The bill borrowed some of the provisions of former bills: I) a private prosecutor was to be permitted to petition a High Court Judge for an order permitting him to proceed with a prosecution or ordering the Solicitor to do so in any case in which the Solicitor had withdrawn the prosecution or simply failed to proceed with it; 2) property owners were to receive the benefits of successful prosecutions by the Solicitor, again on condition that they cooperate with the prosecution; 3) section seven, provided that "Nothing in this Act shall interfere with the right of any person to institute, undertake, or carry on any criminal proceeding."

It was apparent that the only result of the Bill would be to shift the arena from Parliament to the executive for the contest over whether the Government ought to undertake public prosecutions. ${ }^{23}$ All depended upon the content of the regulations which would be issued by the Attorney General. This was recognized in the ensuing debates.

The first voice raised on the motion to go into Committee of the Whole on the bill, that of Mr. B. T. Williams, labeled the bill "a piece of masked legislation" which "gave unlimited powers and invites Parliament to legislate in the dark."284 Moreover, it augured ill, for all "Treasury prosecutions partook more or less of jobbery, and always cost too much." Again and again, the same idea was repeated. Mr. G. Anderson was in favor "of the establishment of Public Prosecutors," but "there was nothing in the Bill to define its scope or [to prevent] its being used to an almost illimitable extent."285 Mr. W. S. Stanhope called for further explanation. And Mr. Morgan Lloyd objected to the vagueness of the bill and the unlimited powers it granted to the Attorney General.

On the other hand, Mr. Radwell supported the bill, since "it would not at all interfere with private prosecutions." ${ }^{328}$ And Mr. Rathbone was still present to support the proposal for public prosecutions, for it was "of great importance that there should be someone beyond the mere private individual to prosecute."287 $\mathrm{Mr}$. Bulwer, who joined with Rathbone, found the bill perfectly plain and clear. He saw particular need for public prosecutions in cases of cominercial fraud. But Lord

\footnotetext{
${ }^{288}$ The Times, long in favor of public prosecutions, could work up only lukewarm support for the bill. March 17, 1879, p. 9, col. 4 .

264244 HANSARD 967 ( 1879$)$.

200 $I d$. at 968.

${ }^{205}$ Ibid.

201 Ibid.
} 
Frederick Cavendish ${ }^{288}$ objected to the form of the bill and thought that the House was entitled to careful estimates of the potential costs involved in the promulgation of such a system. Mr. Sampson Lloyd, however, was willing to concede that the "expense of introducing the new system would be rather formidable, but it would be justified by the results. ${ }^{269} \mathrm{He}$, too, pointed out the necessity for public prosecutions in cases of commercial frauds, especially those arising out of bankruptcy cases.

\section{Then came the major address of Farrar Herschell:270}

Many attempts had been made to deal with the matter; but those efforts had been frustrated, by reason of its always having been attempted not to make use of the present system of prosecutions so far as it extended, but to introduce an entirely new system, by which the whole of prosecutions throughout the country would be carried on by the Government and by a Public Prosecutor. Against such a scheme, whether right or wrong, a host of opponents were raised. All those who conducted prosecutions at the present time, and all those interested in the present mode of conducting prosecutions, became at once opponents of any attempt to wipe away the existing systems. . . . He believed that there was the greatest possible want in this country of a Public Prosecutor-it was felt every day; but, on the other hand, he must, for his part, frankly confess that the mode in which by far the greater number of prosecutions that went on throughout the country were conducted, was eminently satisfactory. ... The distinction should be kept in view, between the existence of a Public Prosecutor whose duty it should be, either by himself or by his subordinates, to see that prosecutions were carried on to their legitimate results, or, when necessary, to institute and carry on the machinery of a prosecution; and the placing of all prosecutions in the country in the hands of Government Prosecutors.

He continued in the vein of the Greaves report of some twenty years before. Under the proposed law, the public prosecutor was to have "general supervision and control," but he was to institute proceedings only when necessary and when no one else had the duty to prosecute. "It was monstrous that a private individual who had suffered great loss should be bound to waste further time and money in prosecuting the individual who injured him."271 And prosecutions should not be permitted to be used for collection of debts. "But it should be the excep-

\footnotetext{
${ }^{208}$ Lord Frederick was soon thereafter to fall victim of assassination, while serving as Secretary for Ireland.

240 244 HANSARD 969 (1879).

${ }^{270} I d$. at 969-70. Herschell was then Recorder for Carlisle and shortly to be Solicitor General and later Lord Chancellor.

st2 Id. at 970.
} 
tion rather than the rule, that prosecutions should be carried on by the Public Prosecutor.")2i2

In spite of the need for supervision of prosecutions, he thought the bill as framed was too vague. "He rejoiced that the Government had taken up the subject, and he hoped that the matter would be brought to a satisfactory conclusion. It was a crying shame that the matter had not been taken up long ago."273 But he was of the opinion that the bill should not be forced through Committee at that point.

The reply was made by the Home Secretary. Assheton-Cross adopted Herschell's technique of agreeing about everything but the conclusion. "I must express my unqualified assent to all the observations that have fallen from [Mr. Herschell]." But he believed that the present bill would effect the very results which the future Chancellor desired.

Sir Richard recited the history of the numerous bills on the subject and the reports of the Select Committee and of what he called the "royal Commission." He then reviewed the systems existent in Scotland and Ireland and touched on the existent methods of public prosecutions in England and Wales and a defense of the proposed legislation: $:^{274}$

If there now is a case which is supposed to be an important one, an application is made to the Secretary of State to take it up as a Government prosecution, and, if it is decided to do so, an order is at once made to consult the Solicitor of the Treasury; and at the present moment there are a number of prosecutions that either by law or practice, the Secretary of State may require the Treasury Solicitor to take up. The Attorney General is therefore, practically, a Public Prosecutor. When this question came before the Judicature Commission, the present Lord Chief Justice made a most elaborate Report on the subject, and he took a line extremely in favour of the appointment of a Public Prosecutor, about which, as an abstract question, there can not be two opinions in this House. But the Lord Chief Justice also took up the notion that every act which the law constitutes a crime is, as such, an offense, not against the individual concerned, but against the community or State. I do not deny that. When, therefore, an offense has been committed, a prosecution should, in the opinion of the Lord Chief Justice, be instituted, not by the individual, but on behalf of the State by its own officer, or, in other words by a Public Prosecutor. ... [Cross read at length from Cockburn's dissenting report made to the Judicature Commission.] That is a complete scheme of public prosecutions by a Public Prosecutor, and it is a scheme to

\footnotetext{
${ }^{273}$ Id. at 972 . ${ }^{273}$ Ibid.

274 $I d$. at $973-74,97.5$.
} 
effectuate which several Bills have been prepared; but $I$ am bound to say that I cannot recommend the House to face the expense of carrying such a scheme into existence. ... I do not propose, therefore, in the scheme which I have laid before the House, to interfere in the ordinary and usual run of criminal prosecutions, either in Quarter Sessions or with the Petty Cases at the Assizes; hut if this scheme is carried into effect, $I$ believe that without interfering with the machinery at present existing, the general tone and conduct of these cases will be raised, and that the standard of the conduct of the cases throughout the country will be equalized. . . .

The scheme which we now propose on behalf of the Government is thisthat there should be a central Public Prosecutor in London. . . . He should be a lawyer, with a fair salary. ... . He would be a permanent officer, and therefore absolutely free from political bias. He should be under the Attorney General, who is, according to the law, at the head of all public prosecutors in this country; and he should have under him a staff of officers to assist him in London, and also assistance in the country at different places. . . . The duties ... are contained in the second section of the Bill.

The third of the major speeches on the bill was delivered by Vernon Harcourt, who attacked the Government's procedure as well as the merits of the proposed legislation: ${ }^{275}$

I think it somewhat extraordinary that the discussion on this Bill should take place on the motion to go into Committee rather than upon the second reading. I am one of the projectors of the idea of a Public Prosecutor, and, indeed, I was Chairman of the Committee upon the Public Prosecutor Bill. Somehow or other that Bill broke down, and I believe really by reason that it was opposed by the most formidable body except the licensed Victuallers, in the country ... I mean Solicitors. I think the Home Secretary has made a very good speech, but I do not see his Speech in the Bill. . . . There is nothing whatever in the Bill but an enormous scheme of patronage under the Attorney General, and a centralization of the patronage throughout the country in his hands.

He pointed out that in his bill, the patronage was to be dispensed by the local authorities. He took exception to the failure to provide for the intervention of the public prosecutor in those cases in which the parties agreed to compromise. He advocated, once again, the necessity for a more extensive system of public prosecutions, a system of the kind which was to be found in the earlier bills which he had introduced.

It fell to the Attorney General to reply to Vernon Harcourt. Helker claimed that the more extensive scheme was also so much more

${ }^{275} I d$. at $977-78$. 
expensive that the country could not afford it. And he suggested that leaving the patronage to the local authorities would result in greater evils than centralizing it in an officer directly responsible to Parliament. He went on in his typically dull style to reiterate the points already made by the Home Secretary.

A Mr. Floyer then rose and demonstrated, at least to the American reader, that their mid-Western Senators are not sui generis, that John Bull, too, has the attributes of insularity and the attitude of "let them eat cake": ${ }^{276}$

He felt that there was nothing which could be more prejudicial to the English character than to imitate the example of various foreign countries, and teach people to look to the Government for everything. If people would not look after their property, it was not right that they should be able to ask the Government to do it for them. It was no doubt, one of the evils of the present system that people would not take the trouble to prosecute in cases where they had been defrauded; but if people were taught to rely on the Government, they would do, as occasionally happened in consequence of our excellent police system-not lock their doors or bar their windows ... that would be a great disadvantage and blow to the English character. In reliance of people upon themselves, and not upon the Government, the English differ from Continental nations-a great system of bureaucracy was foreign to them.

Despite this speech, he was in favor of the bill as it was expected to function by the Home Secretary, but would like to see the details expressed in the bill itself.

The Irish bloc then rose to discuss the proposal. Dr. Mitchell Henry, a disciple of Isaac Butt, demanded more time for debate. He elaborated on the excellence of the Irish system and commended it to the English. The bill was too vague, contained an undue delegation of legislative power to the executive. He suggested that the appointments of the local prosecutors be left to the local authorities and that the Solicitor of Public Prosecutions be made directly responsible to Parliament. He doubted, too, whether the bill made adequate provision for the "little man" who suffered from criminal acts and could not afford to secure redress. Charles Thomas Parnell announced, at length, the inappropriate timing of the bill, and complained about the undue power it concentrated in the Home Secretary. He moved the adjournment of the debate. On this last score, he was joined by the banker, Sir John

${ }^{276} I d$. at $984-85$. It must be admitted that the American system was not even then setting a good example: See 13 L.J. 181 (1878). 
Lubbock. Sir Patrick O'Brian, Mr. Barran, and Dr. O'Leary condemned the power of the individual to institute prosecutions without first appealing to the law officers to undertake the prosecution.

After Sir Richard Assheton-Cross agreed that he would consent to an amendment which would limit the number of assistants to the public prosecutor, and Morgan Lloyd repeated the request that the limitations in the Home Secretary's speech be made specific in the bill; arrangements were made for further debate, and the House went into Committee. The Committee reported progress and the approval of the preamble and the first clause-the title clause-of the bill. ${ }^{277}$

When the debates were resumed on April 24, May I, and May 5, ${ }^{278}$ an amendment offered by Mr. Barry, which would have limited the number of assistant public prosecutors to ten, was shelved in favor of the Home Secretary's own proposal to limit the number to six. And Morgan Lloyd's amendment to change the name of the chief public prosecutor from "Solicitor of Public Prosecutions" to "Public Prosecutor" was rejected in favor of Cross's amendment to change the title to "Director of Public Prosecutions." Cross also carried a motion to limit the salary of the Director to 2,000 pounds per annum, and to have the regulations provide for the areas within which the assistant public prosecutors were to act. Herschell successfully moved for the appointment of the assistant prosecutors by the Home Secretary rather than the Attorney General, and Assheton-Cross's motion to limit the terms of assistants to seven years was also carried.

The bill received its third reading in the Commons on May $6{ }^{279}$ and its first reading, without debate, in the House of Lords on May $8 .{ }^{280}$ Its second reading was moved by the Lord Chancellor, Earl Cairns, who had presided over the Judicature Commission at the time of its Fifth Report. Though not a popular figure, the Chancellor was recognized as the first lawyer of his time and was noted for the lucidity of his speech. His speech in support of the motion was an admirable summary of the problem and the. solution proposed: ${ }^{281}$

Its object was to give effect to the recommendations of a Commission appointed last year to consider the subject, and to establish a Public Prosecutor. It was the opinion of those most conversant with the subject that in the

${ }^{277}$ Outside comment continued to demonstrate that even those in favor of public prosecutions did not care for the bill. See 23 Sol. J. $399-400$ (1879); note 263 supra.

${ }^{278} 244$ HANSARD 1086-91, $1351-53,1562,1773-75$ (1879).

${ }^{270} I d$, at 1806.

${ }^{280} \mathrm{Id}$. at 1944 .

${ }^{282} 246 \mathrm{id}$. at $1335-36$. 
administration of our Criminal law there was no necessity for a general and thorough change; but some of the most eminent witnesses-including the Lord Chief Justice and others-examined by the Commission thought that some changes were required, and that, although the system worked generally well, there were frequently cases in which offenders escaped justice owing to the disinclination of individuals to take up the prosecutions. The object of this Bill was to meet those exceptional cases-such as large commercial frauds, in which private persons could not be expected to undertake the expense of the prosecutions. In order to effect that, the Bill proposed that the Secretary of State should appoint an officer who would be called the Director of Public Prosecutions, and who would have the status of a permanent Under Secretary of State. It would be the duty of the latter, under the Secretary of State and the Attorney General, to carry out prosecutions undertaken by the Government. It was proposed that the Metropolis should be under the direct control, and that the Provinces should be mapped out into certain districts, each having an officer under the Director in London. The proposals of the Bill were rather intended to meet exceptional cases than to disturb the general system at present prevailing; and regulations should be made by the Attorney General, with the approval of the Secretary of State, as to the exceptional cases in which prosecutions would be undertaken, and as to the mode in which the Director of Public Prosecutions would give advice. Solicitors would be appointed for the Assizes, and there would be a staff in the Director's Department, the number of which would depend on the work to be done. It would not be large at first. For the first time the Law Officers would have an office in London, and there would be a continuity of rules in their Department.

It should be noted that much of what Lord Cairns said could not be derived directly from the language of the bill, but must have come from information given to the Lord Chancellor by the Home Secretary.

The former Home Secretary, Lord Aberdare, thought the bill fell short of what the advocates of public prosecutions sought, but admitted that it was a step in the right direction. It fell to Lord Stanley of Alderley to oppose the bill on the ground that "the reputation of these new Public Prosecutors would entirely depend upon the number of convictions they obtained, and it was impossible that they should not be biassed by that."282 This is a succinct analysis of a major problem of public prosecutions in the United States, but it was not at all persuasive to the Lords. The bill received its second reading.

${ }^{289}$ Id. at 1338 . 
On June $19,1879,{ }^{283}$ in committee, Lord Coleridge moved to amend the bill to place the right of appointment of the Director of Public Prosecutions and his assistants in the Attorney General rather than the Home Secretary. The Chancellor replied that the House of Commons had the right to place the patronage in the Home Secretary. When Lord Selborne, ${ }^{284}$ the former Roundell Palmer, spoke in behalf of a Ministry of Justice, the amendment was rejected. And when Lord Coleridge again moved an amendment, this time to provide that only barristers might be appointed as Director of Public Prosecutions, it was rejected by the Chancellor and the House. The bill was reported on June $20,{ }^{285}$ and received its third reading on June $23 .{ }^{288}$ It received the Royal Assent and became law on July 3, I879.

The passage of the statute stirred hardly a ripple. The protagonists of a system of public prosecutions were obviously disappointed. For example, the Times, which had been in the forefront of the movement for over three decades, published the following comment when the newly-created office of Director of Public Prosecutions was filled: ${ }^{287}$

MR. MAULE, Q.C., has been appointed Director of Public Prosecutions. The office is a new one. It was created by an Act, passed last session, intended to remove or diminish a striking blemish in the criminal law of this country. It will be the duty of the Director of Public Prosecutions to institute, under the supervision of the Attorney General, criminal proceedings in cases of importance or difficulty, or where private persons refuse or fail to prosecute, and to give advice to chief officers of police and clerks of Justices respecting prosecutions. He will be aided by six assistants; and, speaking generally, it will be his business and theirs to see that offenses are prosecuted more diligently and systematically than they are. .His duties are large and not too well defined by the statute. They will be sufficient for any one man. Mr. MAULE is a lawyer of considerable experience and repute. He has been engaged in many inquiries on behalf of the Government; and he is placed in a position in which a man of energy and ability may do much good, if not actually work wonders, and may save the country the sight of scandalous miscarriages of justice.

Too much, however, must not be expected of the new machinery. The office of the Public Prosecutor is at last established in deference to the

242247 id. $\times 34-35$.

284 Selborne had once rejected the post of Lord Chancellor under Gladstone. He later occupied that post twice.

285247 HANSARD 290 (1880).

280 Id. at 402 .

${ }^{287}$ Dec. 24,1879 , p. 9, col. 4 . 
opinion of all persons who are acquainted with the working of our criminal law. But it is not the form of office for which most persons have been asking. It is not at all that which the Judicature Commissioners, for example, recommended. When we have got our Director of Public Prosecutions, our system of criminal procedure will still be open to criticism, and will differ widely from those of most other civilized countries. There will remain the great anomaly that the State regards the prosecution of crime with something like unconcern, and that private individuals are free to gratify their passions in a field from which passion should be excluded. . . . In France, and almost everywhere but in England, the business of punishing crime is deemed to be too high and perilous a prerogative to be placed in private hands, and is made peculiarly the duty of the Government. ...

The great fault of our existing system is that while it is everybody's right to prosecute, it is nobody's business to do so. . . . There are few persons who have the courage or the means to bring to justice the guilty authors of a complicated commercial fraud. . . . None but a fool or a rogue, it has been said, will prosecute in an English court of justice; and it is notorious that those who have done so once rarely repeat their example of public spirit. . . . The public little knows of the degree to which the criminal law is perverted into an instrument of petty extortion. ... Honest men are worried with prosecutions which ought never to have been begun; and the sorry compensation is that proceedings against undoubted criminals are abruptly terminated in circumstances which make it morally certain that the prosecution has been bought off or.tampered with. The new Act which Mr. MAULE has to carry out may help a little to diminish these scandals. He will be able, at all events, to attend to details which the Law Officers of the Crown cannot follow. But a Director of Public Prosecutions cannot root up abuses which must, it is to be feared, accompany every system of private prosecution. The Act is, perhaps, most valuable as an earnest and promise of what may exist if ever Parliament should see fit to deny the inborn right of every English. man to set the criminal law in motion whenever it seems good to him in his wisdom or folly.

Thus came to a close the first chapter of the contest between those who wanted public prosecutions and those who preferred to retain the existent system. It was a subject which had engaged the minds and time of the most important legal talent which England produced during that period. In spite of the personalities and issues involved, in spite of the concern of the press and magazines, it has not been considered worthy of a footnote in the various histories of the period, not even those written by Spencer Walpole, who had a direct influence and im- 
portant role in the controversy. ${ }^{288}$ The contemporary comment, ${ }^{289}$ like that of today, ${ }^{280}$ was that the Act accomplished nothing which Brougham was not willing to undertake in 1834 without the help of legislation.

Many theses can be built on the available materials as to the determining factors in the failure of what appeared to be so popular a cause. As Mr. Justice Frankfurter has said, in another setting: "Inertia, of course. But also it is merely one illustration of the lag of reform because of the opposition of lawyers who resist change of the familiar, particularly when they have thriven under some outworn doctrine of law."201 One could talk about the entrenched positions of solicitors, about the issue of patronage, and about the problem of costs. Or you could seek an explanation in Dicey in terms of the movement from laissez faire to statism. In the face of all of these is the fact that Parliament did enact serious reformation of the administration of the criminal law during the period between I854 and 1879 , when public prosecutions could make no headway. ${ }^{292}$ Perhaps the distinguishing factor, raised by Palmerston in 1855 and repeatedly thereafter by others, ${ }^{293}$ was the fear of abuse which is available to the office of public prosecutor.

\footnotetext{
${ }^{288}$ The History of TWenty-Five Years 1856-1880 (1904); History OF ENGLAND ( 1890$)$.

280 I STEPHEN, History of THE CRIMINAL LAW 1501 (1883).

${ }^{200}$ Mathew, The Office and Duties of the Director of Public ProsecuTIONS Io (1950).

${ }^{201}$ Rogers v. Missouri Pacific R.R. Co., 352 U.S. 500, at 539 (1956).

${ }^{202}$ A sampling includes the following: An Act for diminishing Expense and Delay in the Administration of Criminal Justice, 18 \& 19 Vict. c. 126 (1855); An Act to empower the Court of Queen's Bench to order certain Offenders to be tried at the Central Criminal Court, 19 \& 20 Vict. c. 16 (1856); An Act to improve the Administration of the Law so far as Respects summary Proceedings before Justices of the Peace, 20 \& 2 I Vict. c. 43 (1857); An Act to amend the Law concerning the Powers of Stipendiary Magistrates and Justices of the Peace in Certain Cases, 21 \& 22 Vict. c. 73 (1858); An Act to prevent Vexatious Indictments for certain Misdemeanors, 22 \& 23 Vict. c. 17 (1859); An Act for the more speedy Trial of certain Homicides committed by Persons subject to the Mutiny Act, 25 \& 26 Vict. c. 65 (1862); An Act to enable Cities, Towns, and Boroughs of Twenty five thousand Inhabitants and upwards to appoint Stipendiary Magistrates, 26 \& 27 Vict. c. 97 (1863); An Act to remove some Defects in the Administration of Criminal Law, 30 \& 31 Vict. c. 35 (1867); An Act to amend the Law relating to the office of the Clerk of Assize and offices united thereto, and to certain fees upon Orders for Payment of witnesses in criminal proceedings, 32 \& 33 Vict. c. 89 (1869); An Act for the more effectual Prevention of Crime (Habitual Offenders), 32 \& 33 Vict. c. 99 ( 1869); An Act for the more effective Prevention of Crime, 34 \& 35 Vict. c. 112 (1871); An Act to amend the practice of the Courts of Law with respect to Review of the Decisions of Justices, 35 \& 36 Vict. c. 26 (1872); An Act to amend the Law with respect to the Appointment, Payment and Fees of Clerks of Justices of the Peace and Clerks of Special and Petty Sessions, 40 \& 4 I Vict. c. 13 (1877).

${ }^{203}$ See, e.g., notes 122 and 167 supra
} 
Part of the fear was certainly emotional. ${ }^{294}$ But part of it was rational. ${ }^{206}$ It would seem that the English law saw the virtues of public prosecutions and the evils of private prosecutions. They sought the compromise which would afford it the best of two possible worlds. The immediate result was a failure which is another story. But American experience with prosecuting attorneys does not suggest that the English erred on the wrong side.

294 James Fitzjames Stephen, directing himself to another issue, wrote that it represented "the final triumph of a feeling which played a very conspicuous part in our history, excessive jealousy of the procedure founded upon the version of the Roman law which prevailed all over the Continent, and which in this country was associated with arbitrary power. . . Suggestions as to the Reform of the Griminal Law, 2 NiNETEENTH CENTURY 737,750 (1877).

205 " It is thus absurd to quarrel with the law when a crime is not detected. The fault, if there is one at all, lies in the passion of the English people for personal frecdom, and in their intolerance of personal restraint or interference for any purpose whatever. This is the real obstacle which has always prevented the appointment of any permanent officer with inquisitorial powers specially charged with the detection of offences; and so long as we choose to enjoy an exemption from the abuses to which the existence of such officials would or might lead, we must be content to pay the price in the form of the occasional impunity of offenders." Stephen, The Criminal Lazw and the Detection of Crime, 2 Cornhill Magazine 697, 698-99 (1860). 